UCRL-53437

Distribution Category UC-11

UCRL -53437

DEE4 005750

\title{
Riola Release Report
}

\author{
E. C. Woodward
}

Manuscript date: August 4, 1983

\section{DISCLAIMER}

This report was prepared as an acoount of work sponsored by an ajency of the United States Government. Neither the United States Government nor any agency thereof, nor any of their employees, makes any warranty, express or implied, or assumes any legal liability or responsibility for the accuracy, completeness, or usefulness of any information, apparatus, product, or process discloed, or represents that its uxe would not infringe privately owned rights. Reference herein to any specific commercial product, procese, or arvice by trade name, trademark. manufacturer, or otherwise does not nocessarily constitute or imply its endorsement, recommendation, of favoring by the United States Government or any agency thereof. The views and opinions of authors expreseed berein do nol necessarily state or reflect thoue of the United States Government or any agency thereof.

\author{
NOTICE \\ PORTIONS OF THES REPOAT ARE ILLECURLE. \\ It has tsasi reproduced from the lisis! \\ avaibstis ocity to perimit the hroadest \\ pesei?" 2 asdirizinity.
}

\section{LAWRENCE LIVERMORE NATIONAL LABORATORY University of California - Livermore, California - 94550}




\section{Contents}

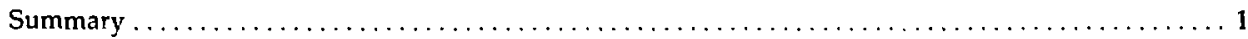

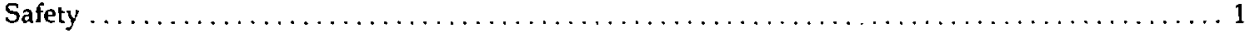

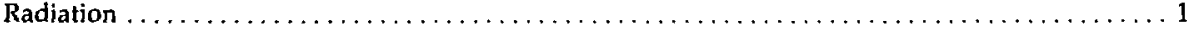

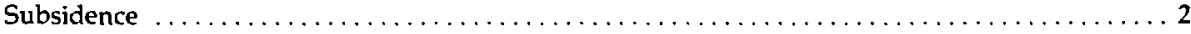

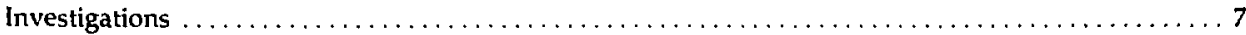

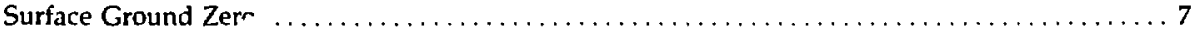

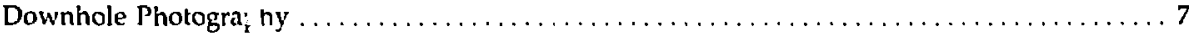

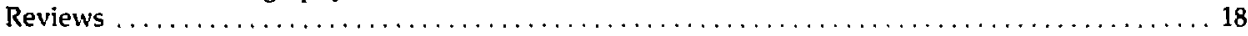

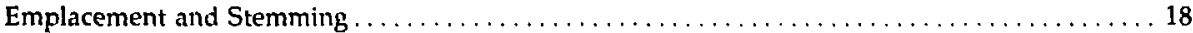

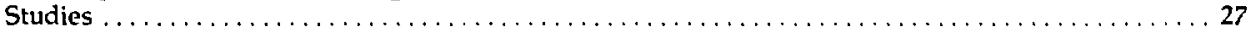

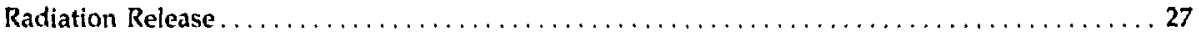

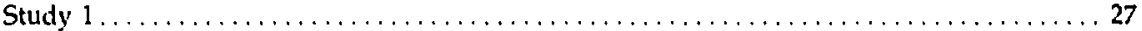

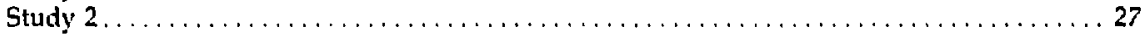

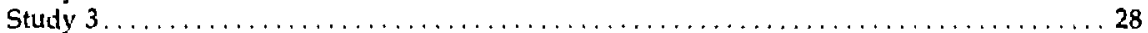

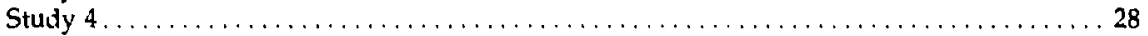

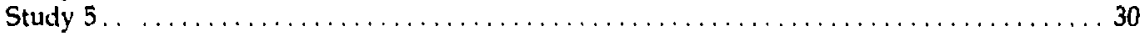

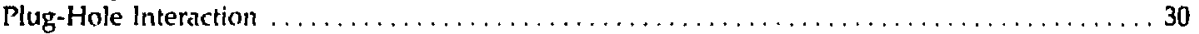

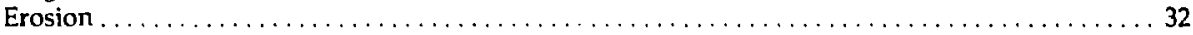

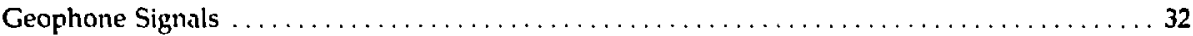

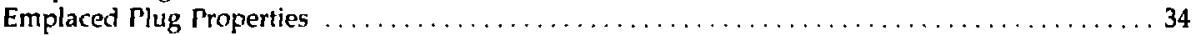

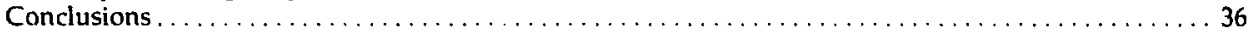

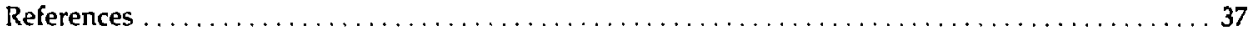




\section{Riola Release Report}

\section{Summary}

Eleven hours after execution of the Riola Event (at 0826 PDT on 25 September 1980) in hole U2eq of the Nevada Test Site (NTS), a release of radioactivity began. When the seepage stopped at about noon the following day, up to some $3200 \mathrm{Ci}$ of activity had been dispersed by light variable winds. Table 1 is a chronology of events.

On 26 September, examination of the geophone records showed six hours of low-level, but fairly continuous, activity before the release. Electrical measurements indicated that most cables were still intact to a depth below the stemring platform. A survey of the ground zero area showed that the seepage came through cracks between the surface conductor and the pad, through cracks in the pad, and through a crack adjacent to the pad around the mousehole (a small hole adjacent to the emplacement hole).

To preclude undue radiation exposure or injury from a surprise subsidence, safety measures were instituted. Tritium seepage was sufficient to postpone site activities until a box and pipeline were emplaced to contain and remove the gas.

A thorough engineering review showed that the emplacement and stemming had been done according to the approved plan and established procedures.

Downholt photography revealed the emplacement hole to be significantly enlarged for $150 \mathrm{ft}$ of depth encompassing the zone of the stemming platform. It also showed that only the core portion of the platform suppoted by the plug support ring at $699 \mathrm{ft}$ remained and that the emplacement pipe had undergone column failure well below the stemming platform at a depth of $856 \mathrm{ft}$.

Radiation release modeling and calculations were generally consistent with observations. Plug-hole interaction calculations showed that the alluvium near the bottom of the plug may have been overstressed and that improvements in the design of the plug-medium interface can be made. Experimental studies verified that the surface appearance of the plug core was caused by erosion, but, assuming a normal strength for the plug material, that erosion alone could not account for the disappearance of such a large portion of the stemming platform. Samples from downhole plug experiments show that the plug may have been considerably weaker than had been indicated by quality assurance $(Q A)$ samples.

\section{Safety}

\section{Radiation}

To prevent undue exposure, extensive radiation monitoring was done in the area of hole U2eq. By $1200 \mathrm{~h}$ Friday, 26 September 1980, the release of radioactive fission products driven by cavity gas pressure ceased. Subsequent occasional detection of these releases resulted from atmospheric pressure lows that caused the cavity gas to "breathe."

The release of tritium contained in HT (hydrogen-tritium) gas and HTO (hydrogentritium-oxygen) vapor followed a different pattern. Sample concentrations increased from about $2 \mu \mathrm{Ci} / \mathrm{cm}^{3}$ on September 26 to about $3 \mathrm{mCi} / \mathrm{cm}^{3}$ on October 10. Because this concentration was in excess of the maximum permissible concentration for a $40-\mathrm{h}$ work week, operations around hole U2eq were postponed and additional samples were taken around surface ground zero (SGZ). Figure 1 illustrates the tritium concentrations near Riola in mid-October 1980.

A box that was $20 \mathrm{ft}$ square by $6 \mathrm{ft}$ high wats built and emplaced over surface ground zero, ayd a pipeline and pumping equipment were installed to remove contaminated air from the box and inject it into the Nessel (U2ep) chimney through the postshot hole (U2ep-PS1A). Figure 2 is 7 schematic of the gas-disposal system, and Fig. "show's the box and pipe leading from it. Facil/ties and 
Table 1. Chronology of events and available information subsequent to and until termination of the Riola release.

\begin{tabular}{|c|c|}
\hline $\begin{array}{l}\text { September } 25 \\
\text { Time }\end{array}$ & \\
\hline 0826 & $\begin{array}{l}\text { Zero lime. Geophones register greater than } 10 \mathrm{~V} \text { full scale for } 12 \mathrm{~s} \text {, greater than } 5 \mathrm{~V} \text { full scale for } 21 \mathrm{~s} \text {, } \\
\text { and decrease to background at about } 90 \mathrm{~s} \text {. }\end{array}$ \\
\hline 0906 & $\begin{array}{l}\text { Bonarda (U3gy) collapse. Riola geophones register } 1 \mathrm{~V} \text { full scale, then decrease to background in } \\
\text { about } 30 \mathrm{~s} \text {. }\end{array}$ \\
\hline 0951 & First prompt gas sample laken. End of hose at $1227 \mathrm{ft}$. \\
\hline 1200 & Geophones register occasional signals of up to $0.3 \mathrm{~V}$. \\
\hline 1350 & Geophones begin to register very frequeni small signals with occasional signals of about $1 \mathrm{~V}$. \\
\hline 1506 & $\begin{array}{l}\text { Prompt gas sampling completed for the day, Cables still intact to about } 1280 \mathrm{ft} \text {, as measured on } \\
\text { Cliper and D-cable. Slifer oscillator indicates uncrushed Slifer cable to } 1230 \mathrm{ft} \text {. }\end{array}$ \\
\hline 1922 & Surface ground zero (SGZ) RAMS detects initial seepage of radioactivity to the atmosphere. \\
\hline 1925 & Perimeter RAMS No. 6 (2 ft southwest of GZ) reads $13 \mathrm{mR} / \mathrm{h}$ \\
\hline 1950 & SGZ RAMS reads $500 \mathrm{mR} / \mathrm{h}$, the highest reading recorded, Geophone signals become infrequent. \\
\hline 2130 & $\begin{array}{l}\text { SGZ RAMS reads } 166 \mathrm{mR} / \mathrm{h} \text {. Perimeter RAMS reads } 20 \mathrm{mR} / \mathrm{h} \text {, and U3gv portable units read } \\
0.4 \mathrm{mR} / \mathrm{h} \text {. }\end{array}$ \\
\hline \multicolumn{2}{|l|}{ September 26} \\
\hline 1030 & SGZ RAMS reads $15 \mathrm{mR} / \mathrm{h}$. \\
\hline 1100 & $\begin{array}{l}\text { Measurements show D-cable broken at } 99 \mathrm{ft} \text {, Cliper cable broken at } 843 \mathrm{ft} \text {, and gas-sampling hose } \\
\text { pulled } 65 \mathrm{ft} \text { downhole. Readings belween } 30 \text { and } 1500 \mathrm{mR} / \mathrm{h} \text { obtained on, in, and around concrete } \\
\text { pad at SGZ. }\end{array}$ \\
\hline 1200 & SGZ RAMS reads background. \\
\hline 1630 & Measurement of diagnostics cables shows them broken al cable fanout at about $865 \mathrm{ft}$. \\
\hline
\end{tabular}

equipment supporting a downhole camera appear in the background. The holding capacity of alluvium for gases injected at some depth is discussed in "Waste Gas Dispose" . Alluvium."1

Lawrence Livermore National Laboratory's Health and Safety Department at NTS (LLNL-N), assisted by Reynolds Electric Company's (REECo's) Rad Safe, continued to monitor the working enviroment throughout all on-site activities. To ascertain the quantities and proportions of the constituent gases and to evaluate any explosive hazard, LLNL's Nuclear Chemistry Department took both surface and downhole samples, ${ }^{2}$ Tracer gas measurements show that some 50 million litres of noncondensable gases were produced in the Riola cavity.

\section{Subsidence}

To guard against the hazard of a surprise subsidence or collapse to the surface, an important safety consideration, geophone signals were monitored continuously. Table 2 summarizes the signals of interest, and Figs. 4 through 6 illustrate some of the signals summarized in the table. More geophone signals are contained in "Riola Information for CEP." 3

The lengths of the downhole signal cables were monitored periodically, particularly before each new activity near hole L'2eq was undertaken. About three-fourths of the prompt diagnostic cables remained intact to depths below the stemming platform. No significant changes from the conditions found on September 26 occurred.

After the initial downhole photography had revealed no evidence of a large-scale subsurface collapse and a study of collapse experience showed that collapse to the surface at the Riola scaled depth of burial had never taken place, operations requiring heavy equipment near $S G Z$ were permitted and the investigation was completed without incident. 


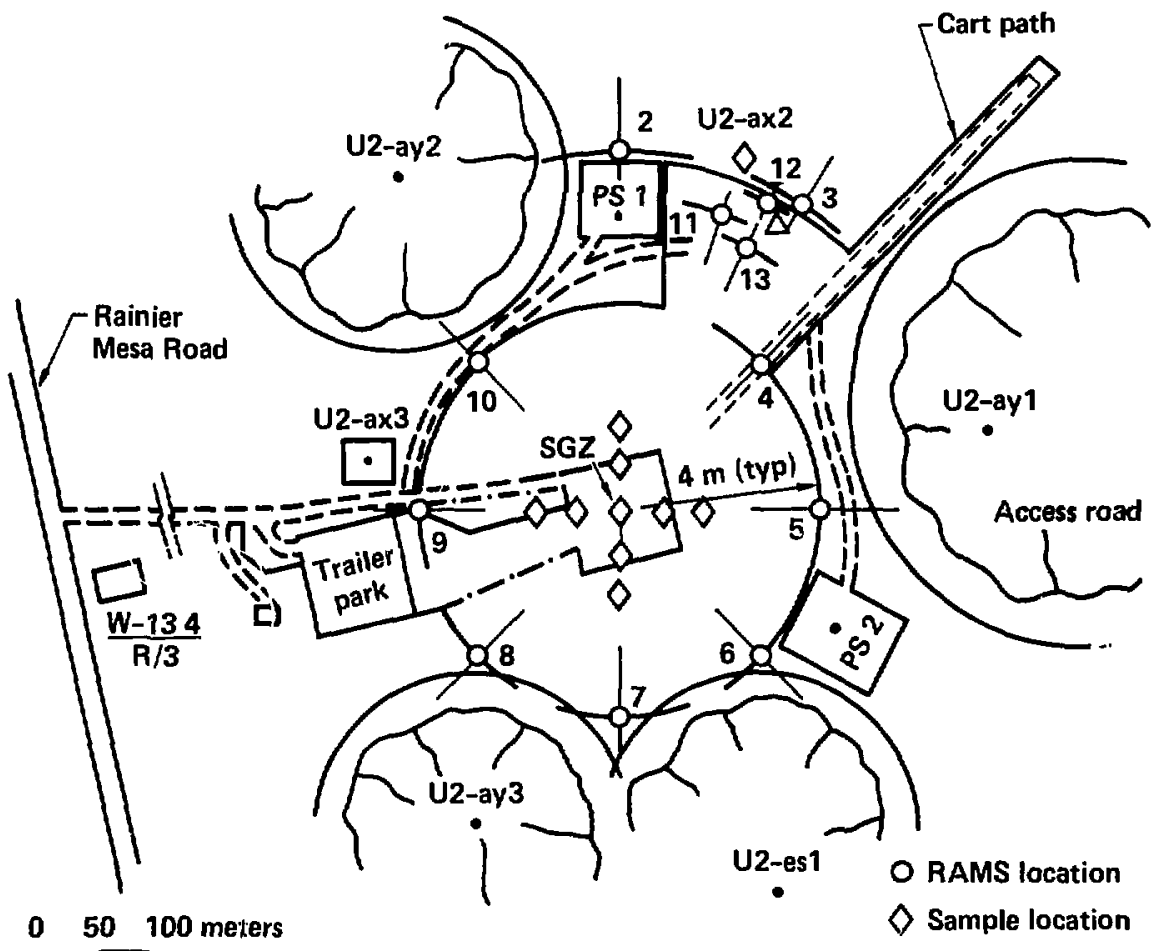

\begin{tabular}{|c|c|c|c|}
\hline Location & Activity $\left(\mu \mathrm{Ci} / \mathrm{cm}^{3}\right)$ & Location & Activity $\left\{\mu \mathrm{Ci} / \mathrm{cm}^{3}\right\}$ \\
\hline SGZ & $\begin{array}{l}8.0 \times 10^{-4} \mathrm{HT} \\
2.2 \times 10^{-6} \mathrm{HTO}\end{array}$ & $200 \mathrm{ft} \mathrm{S}$ of $\mathrm{SGZ}$ & $\begin{array}{l}4.0 \times 10^{-5} \mathrm{HT} \\
7.0 \times 10^{-6} \mathrm{HTO}\end{array}$ \\
\hline $100 \mathrm{ft} N$ of $S G Z$ & $\begin{array}{l}3.9 \times 10^{-6} \mathrm{HT} \\
1.2 \times 10^{-9} \text { HTO }\end{array}$ & $100 \mathrm{ft} W$ of $S G Z$ & $\begin{array}{l}5.0 \times 10^{-5} \mathrm{HT} \\
3.2 \times 10^{-8} \mathrm{HTO}\end{array}$ \\
\hline $200 \mathrm{ft} N$ of SGZ & $\begin{array}{l}1.0 \times 10^{-4} \mathrm{HT} \\
1.0 \times 10^{-8} \mathrm{HTO}\end{array}$ & $200 \mathrm{ft} W$ of SGZ & $\begin{array}{l}4.0 \times 10^{-5} \mathrm{HT} \\
6.5 \times 10^{-8} \mathrm{HTO}\end{array}$ \\
\hline $100 \mathrm{ft}$ E of SGZ & $\begin{array}{l}1.1 \times 10^{-4} \mathrm{HT} \\
1.5 \times 10^{-8} \mathrm{HTO}\end{array}$ & Near U2az-2 & $\begin{array}{l}4.0 \times 10^{-5} \mathrm{HT} \\
3.4 \times 10^{-7} \mathrm{HTO}\end{array}$ \\
\hline $200 \mathrm{ft} E$ of $S G Z$ & $\left\{\begin{array}{l}3.0 \times 10^{-5} \mathrm{HT} \\
2.0 \times 10^{-7} \text { HTO }\end{array}\right.$ & $\begin{array}{l}\text { Maximum permissible } \\
\text { concentration for } 40 \mathrm{~h}\end{array}$ & $\begin{array}{l}2.0 \times 10^{-3} \mathrm{HT} \\
5.0 \times 10^{-6} \mathrm{HT}\end{array}$ \\
\hline $100 \mathrm{ft} S$ of SGZ & $\begin{array}{l}9.0 \times 10^{-5} \mathrm{HT} \\
1 \times 10^{-9} \mathrm{HTO}\end{array}$ & & \\
\hline
\end{tabular}

Figure 1. Tritium activity at he Nevada Test Site (NTS), mid-October 1980. 


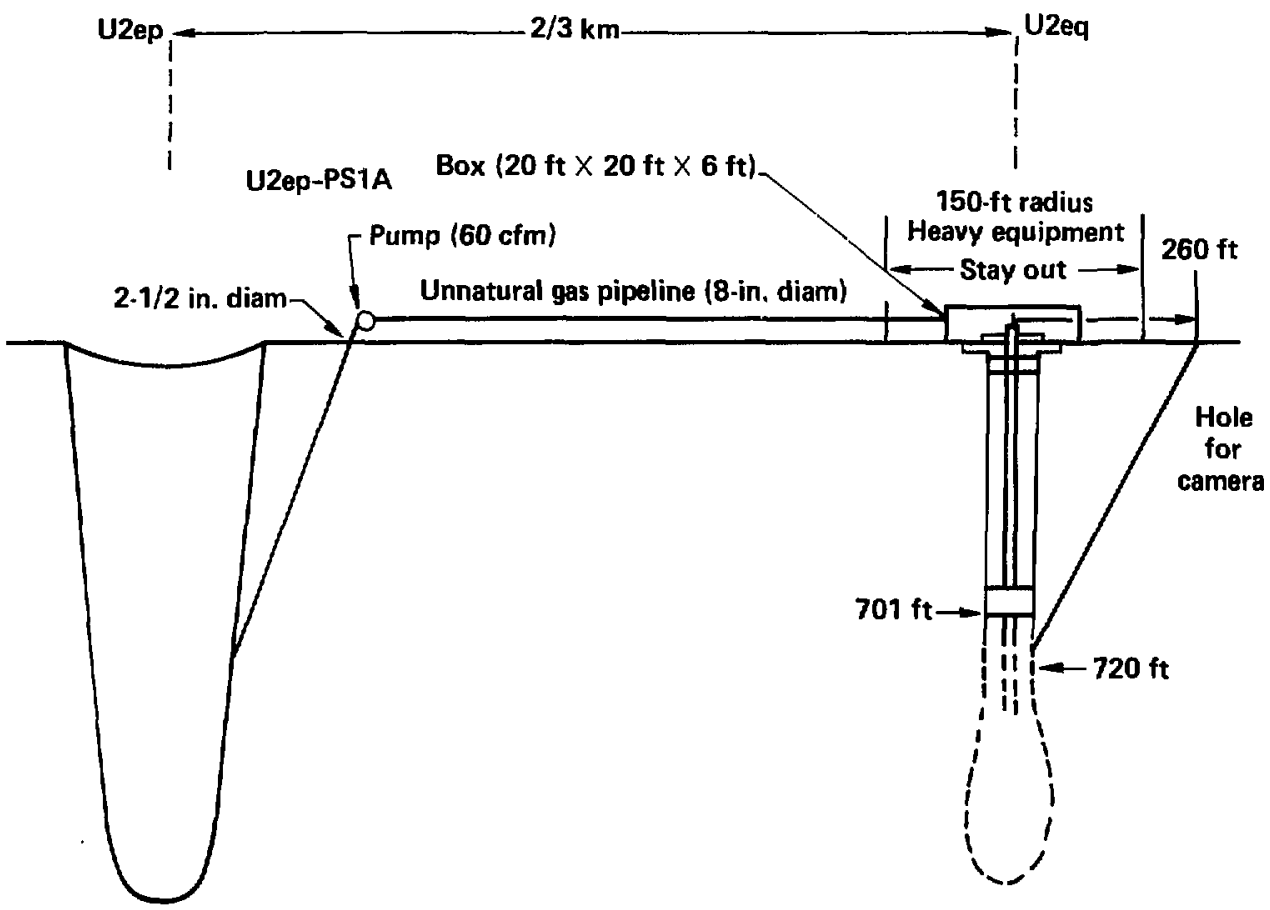

Figure 2. Gas-disposal system.

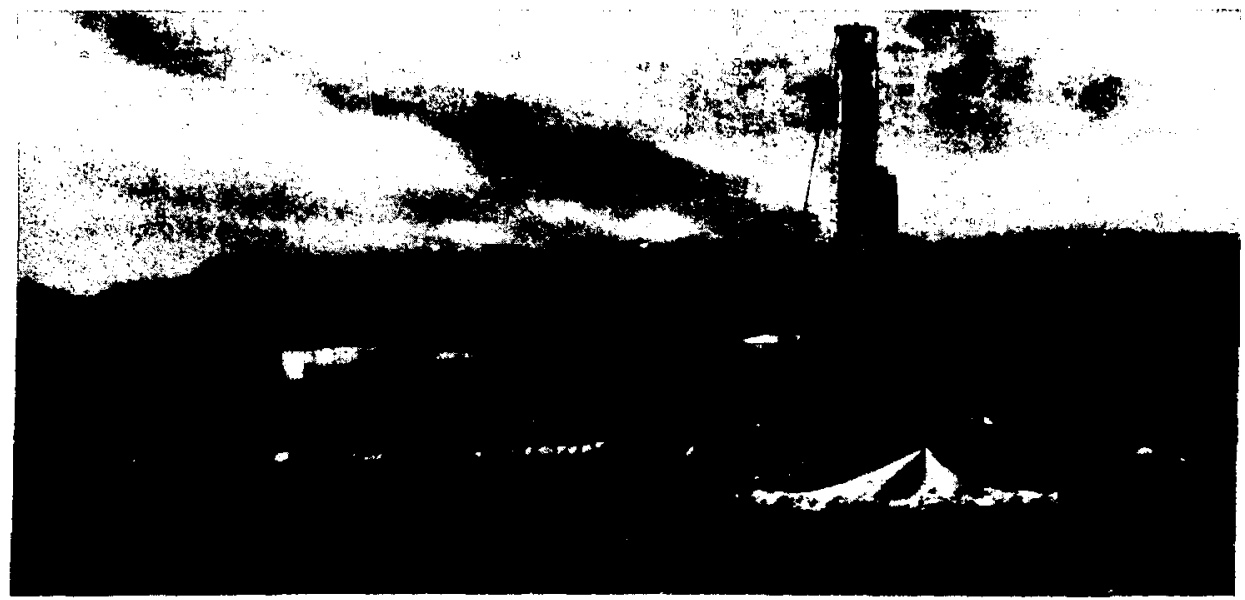

Figure 3. Box built over SGZ and pipeline leading from it. 


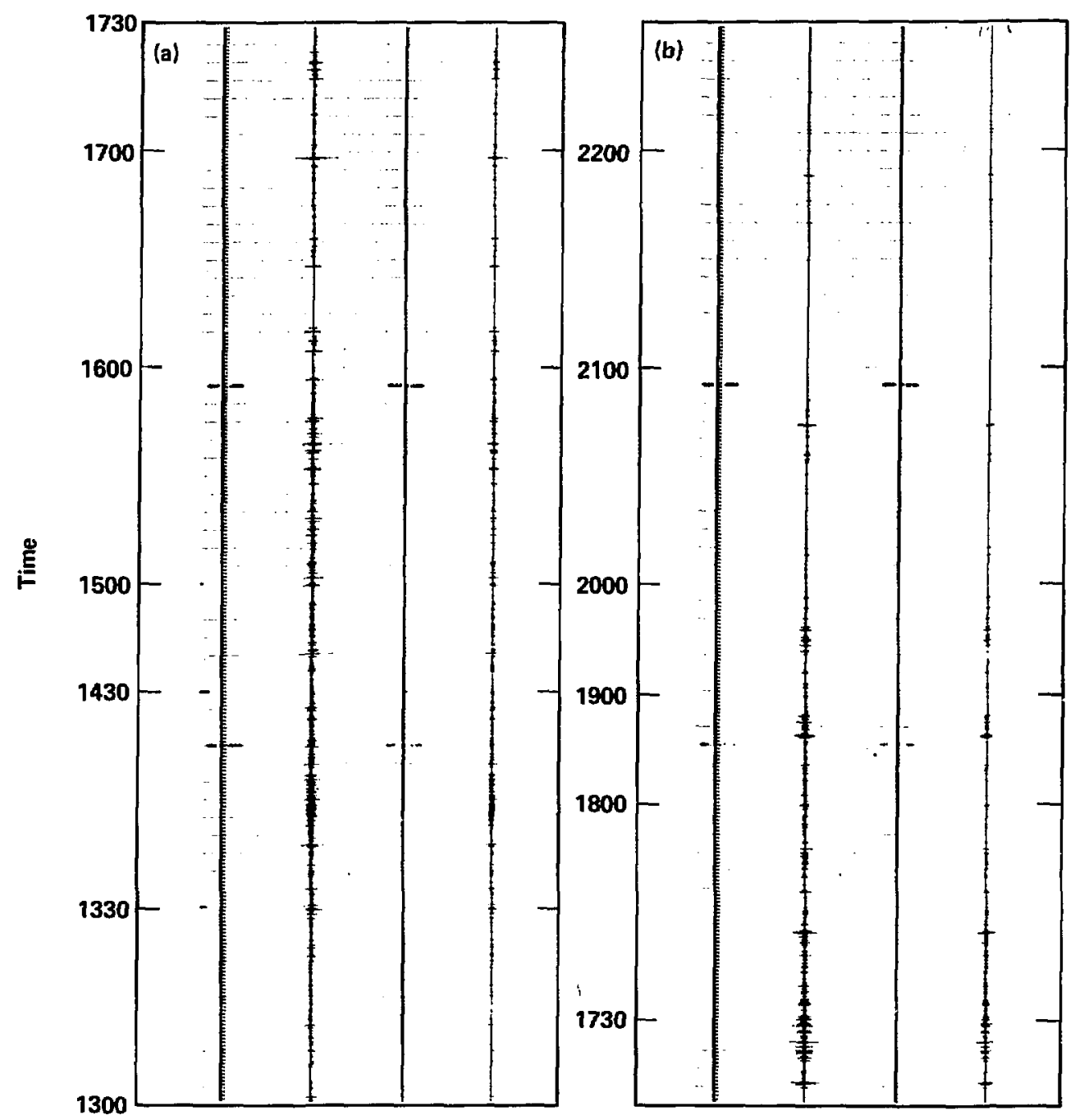

Figure 4. Geophone activity (a) from 1300 to $1730 \mathrm{~h}$ and (b) from 1730 to $2200 \mathrm{~h}$. 

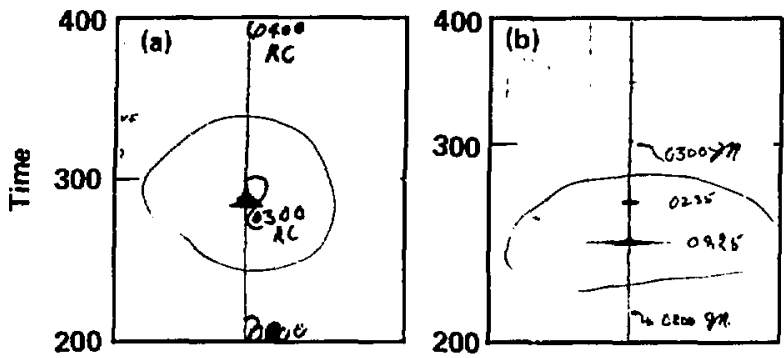

Figure 5. North geophone record of (a) earthquake and (b) later activity.

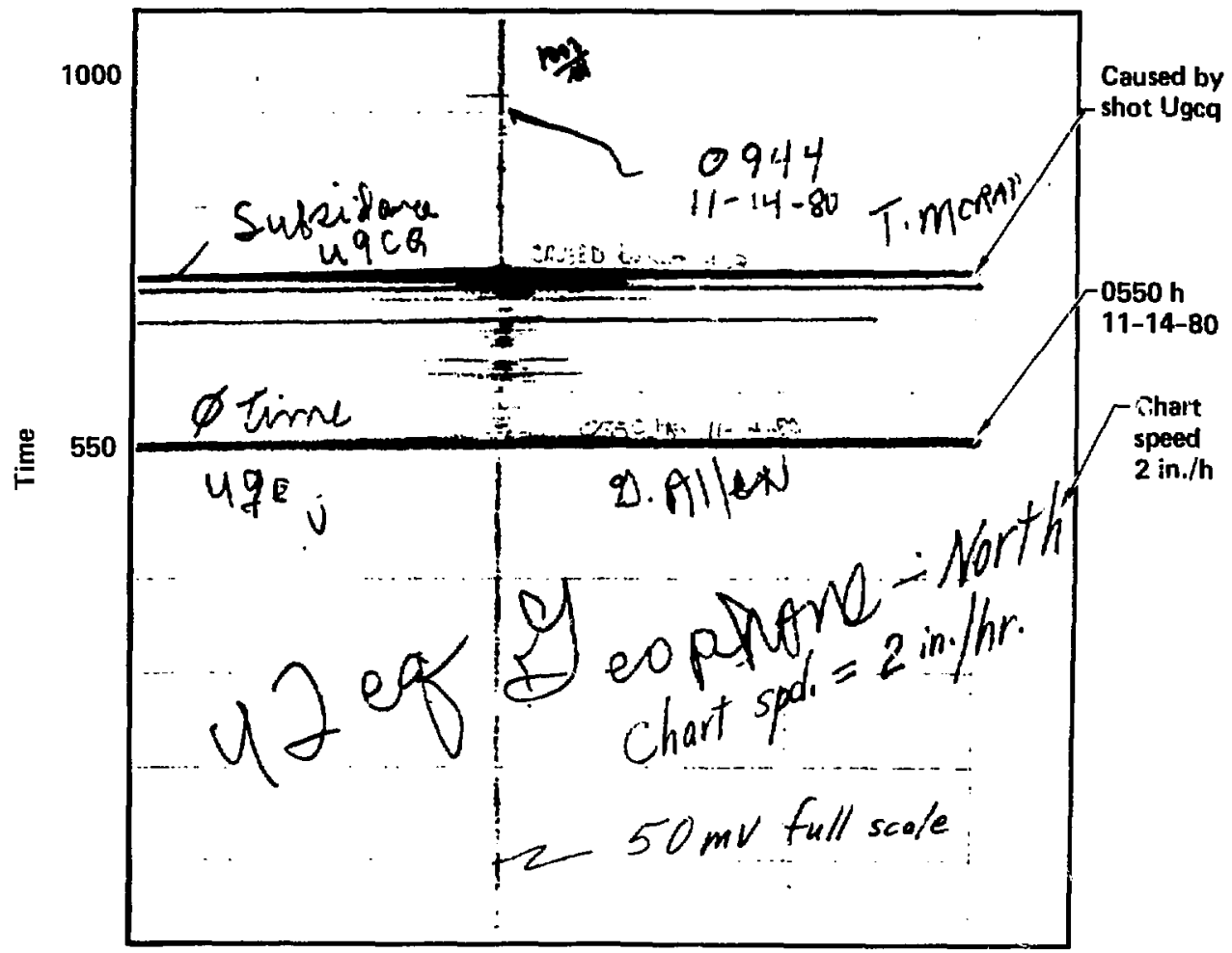

Figure 6. North geophone record at U2eq following shot U9cq (Dauphine). 
Table 2. Riola geophone records.

\begin{tabular}{|c|c|c|c|}
\hline \multicolumn{2}{|c|}{ Time } & \multirow{2}{*}{$\begin{array}{l}\text { Signal size } \\
\text { full swing } \\
\text { (mV) }\end{array}$} & \multirow[b]{2}{*}{ Remarks } \\
\hline Day & Hour & & \\
\hline \multirow[t]{5}{*}{$9 / 25 / 80$} & 0826 & $\begin{array}{cl} & >10,000 \\
& >5,000 \\
\text { Decrease to background }\end{array}$ & $\begin{array}{l}\text { Saturated } 12 \mathrm{~s} \\
\text { Saturated } 21 \mathrm{~s} \\
\text { Ringing to } 120 \mathrm{~s}\end{array}$ \\
\hline & 0907 & 900 & ～10 s following Bonarda collapse \\
\hline & $\begin{array}{l}1329 \text { to } \\
1556\end{array}$ & 200 to & $\begin{array}{l}\text { Mostly }-200 \mathrm{mV}, 500 \mathrm{mV} \\
\text { about once in } 10 \mathrm{~min}, 1,000 \mathrm{mV} \text { ahout once per hour }\end{array}$ \\
\hline & 1700 & 1,500 & Briaf \\
\hline & $\begin{array}{l}1740 \text { to } \\
1947\end{array}$ & $\begin{array}{l}20010 \\
1,000\end{array}$ & $\begin{array}{l}\text { Mostly } \sim 200 \mathrm{mV}, 500 \mathrm{mV} \\
\text { about once in } 10 \mathrm{~min}, 1,000 \mathrm{mV} \text { about once per hour }\end{array}$ \\
\hline $11 / 8 / 80$ & 0250 & 4 & Earthquake off Eureka, Calitornia \\
\hline $11 / 11 / 80$ & 0225 & 12 & Riola activity \\
\hline $11 / 14 / 80$ & 0850 & $=-50$ & Dauphine (U9cq) \\
\hline
\end{tabular}

\section{Investigations}

\section{Surface Ground Zero}

On 26 September 1980, a radiation survey team carefully monitored the area near ground zero. They found that the largest sources of radiation were the ladder support holes. Radiation was also detected between the surface conductor and the pad, along some cracks in the pad, and along a crack south of the pad, encircling the mousehole. Figure 7 (a) shows the results of a survey at $1230 \mathrm{~h}$, and Fig. $7(b)$ shows the results of a partial survey at $1500 \mathrm{~h}$. The north side of the pad area, viewed from the west, is shown in Fig. 8(a). Figure $8(b)$ shows the two ladder holes having the highest radiation readings: $1.5 \mathrm{mR} / \mathrm{h}$ for the hole in the center of the figure, and $0.5 \mathrm{R} / \mathrm{h}$ for the hole at right. Figure 8(c), from the south, shows a crack that had a reading of $150 \mathrm{mR} / \mathrm{h}$. Readings within the surface conductc: were $30 \mathrm{mR} / \mathrm{h}$, which was background for this location at the time.

In January 1982, the pad was sawed into pieces and removed, visual and documentary photography were performed, and soil samples were taken. The results are contained in "Riola Soil Sample Results"4 and in "Riola Graphical Soil Sample Reults."5 Visually, no new information was acquired. The soil samples showed a fairly uniform permeation of tritium throughout the material near ground zero.

\section{Downhole Photography}

For downhole photograply, three postshot holes were drilled to intersect the emplacement hole. The first and second holes were, respectively, helow and above the stemming platform location, while the third was higher in the hole but necessarily below the bottom of the surface conductor. Table 3 lists the sputding (start of hole) distances and directions from SGZ and the estimated intersection depths for the three holes. Figure 9 illustrates the site geometry. "U2eq PostShot Hole Drilling Summary" provides a brief history of these holes.

Six downhole photography runs have provided pictures of the interior of the emplacement hole, the emplacement hardware, the cables, and what remains of the stemming platform. Photographs and videotape records encompass the hole hetween depths of 300 and $1170 \mathrm{ft}$. The camera, a product of V. Brugman and his Photo Applications Group at LLNL-N, contains both photographic and video cameras and has pan, tilt, and zoom capabilities (Fig. 10).

Uppermost entry into the emplacement hole was made at a depth of $301 \mathrm{ft}$. Except for the smaller number of cables, both the hole and emplaced hardware are similar in appearance to their prestemmed condition. The upper 
(a)

Gas-sampling cables

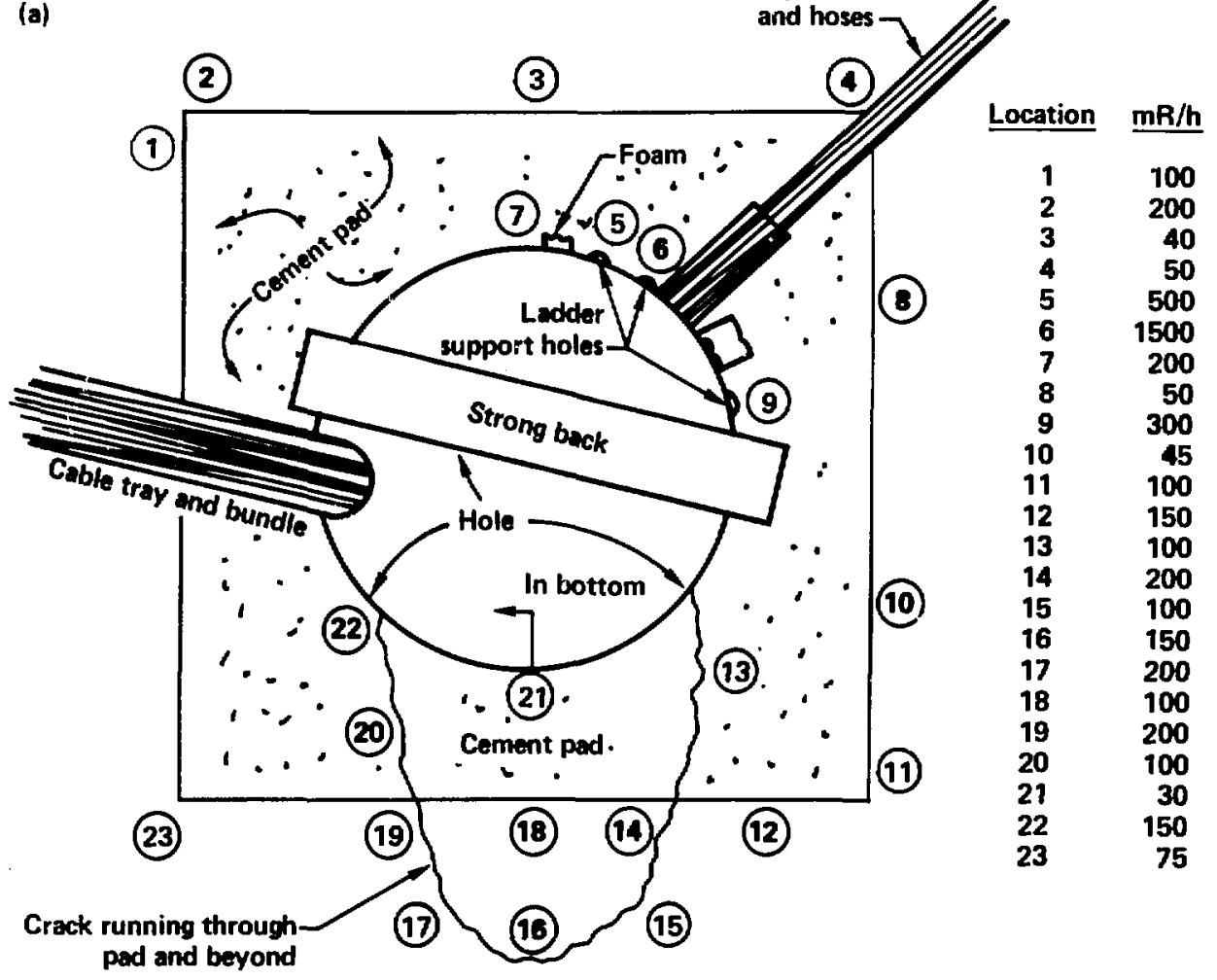

(b)

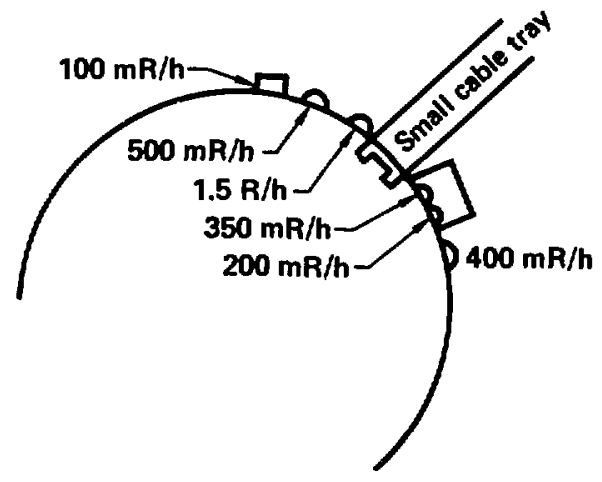

Figure 7. Results of surveys at (a) 1230 and (b) 1500 h, 26 September 1980. 

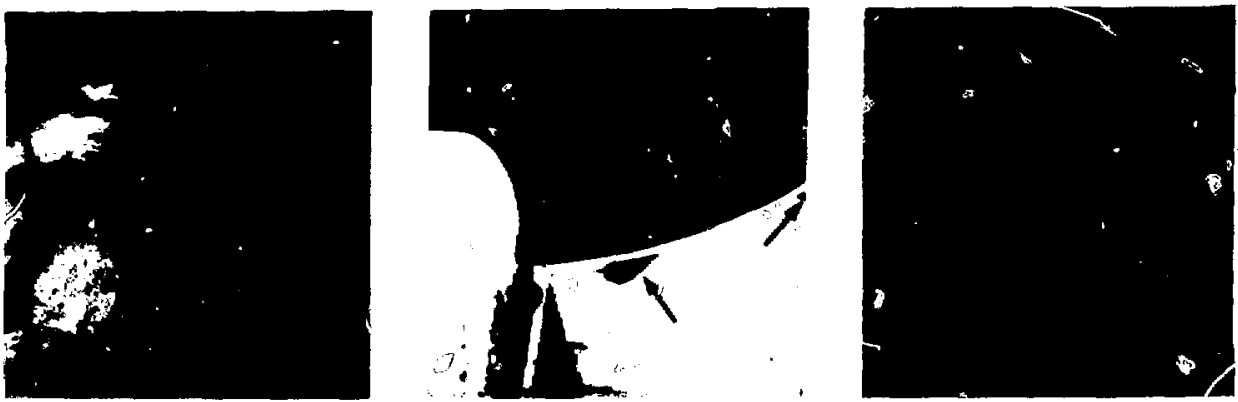

Figure B. (a) North side of pad area, viewed from the west; (b) ladder' support holes having highest radiation readings; (c) view of pad from south, showing crack with radiation reading of $150 \mathrm{mR}$.

vacuum-demand valve of the prompt-gas sampling system is shown in Fig. 11. It is located at a depth of $\$ 3+\mathrm{ft}$, some $6 \mathrm{ft}$ deeper than when it wai emplaced. This displacement agree well with the estimated 65 it of surface-gas sampling hose that disappeared downhole subsequent to Riola D-day sampling activities, but prior to reentry on $D+1$. The hose now ends at $490 \mathrm{ft}$. Down to a depth of $655 \mathrm{ft}$, the hole appears to be unsltered from its preshot condition $A$ t this depth the hole hecomes enlarged and remains enlarged to a depth of $805 \mathrm{ft}$ [Figs. 12(a) and (b;.. This cnlargement, which amounts to an increase in radius of 2 to $f \mathrm{ft}$, is uniform at some depths and not at others [Figs. :3(a) and (b)].

The top of the plug (Jig. 14) was at a depth of $685 \mathrm{ft}$, the as-built depth. Figures 15 (a) through (d) show what remains of the stemming platform and the plug support ring located at $699 \mathrm{ft}$.

Figure 16 is a mosaic of seven photographs showing, from the opposite side, what remains of the lower portions of the stemming platform. The large cable snarl near $780 \mathrm{ft}$, seen in Fig. 17, is the result of cable breakage and stemming fall. Figures 18(a) and (b) show the bend above and the broken end of the emplacement pipe at $856 \mathrm{ft}$.
The broken end of the fallen lower portion of the emplacement pipe at $1059 \mathrm{ft}$ and the bend below are shown in Figs. $18(c)$ and $18(d)$.

At alout $1135 \mathrm{ft}$, the loster gage portion of the hole sands and the top of the chimmey is encountered (Fig. 19) The fallen emplatement pipe disappears in the rubble at $1170 \mathrm{ft}$ (Fig. 20). A mosaic of 11 photographs of the rhimney, looking down at 45 deg from vertical, is shown in Fig. 2?. We estimate that the rubble mects the chimney wall $a$ about a distance of $50 \mathrm{ft}$. Figure 22, a view looking up from $310 \mathrm{ft}$, shows looth a gage emplacement hole and the cable that supports the carmera as it enters the empiacement hole through one of the post-shot holes.

In summary, $150 \mathrm{ft}$ of the emplacewent hole was $c$ arged significantly, well above and below the stemming platform location. We also saw the remains of the stemmin latform, which resemble the frustrum of a coicc, and its upper portion, which remains bonded to the cables but not to the emplacement pipe; an intact plug support ring (42 in. diam): and the emplacement pipe, showing column failure at a depth of $856 \mathrm{ft}-50 m e 535 \mathrm{ft}$ ahove the working point.

Table 3. Riola photography postshot holes.

\begin{tabular}{|c|c|c|c|c|}
\hline Hole & $\begin{array}{l}\text { Distance } \\
\text { trom SGZ (ft) }\end{array}$ & $\begin{array}{l}\text { Direction } \\
\text { from SG?: }\end{array}$ & $\begin{array}{l}\text { Intersection } \\
\text { deplh (ft) }\end{array}$ & Remarks \\
\hline U2eq PS-3AA & 260.1 & $S 63^{\circ} 46^{\prime} E$ & 695 & $\begin{array}{l}\text { En:zred enlarged emplacement hole } \\
\text { some } 9 \text { ft off axis of U2eq }\end{array}$ \\
\hline U2eq PS-4A & 239.8 & Iง $63^{\circ} 57^{\prime} \mathrm{W}$ & 671 & $\begin{array}{l}\text { Broke through to emplacement hole } \\
\text { from } 671 \text { to } 673 \mathrm{ft}\end{array}$ \\
\hline U2eq PS-1DA & $15 . B$ & S $59^{\circ} 29^{\prime} \mathrm{E}$ & 301 & Clase to vertical \\
\hline
\end{tabular}



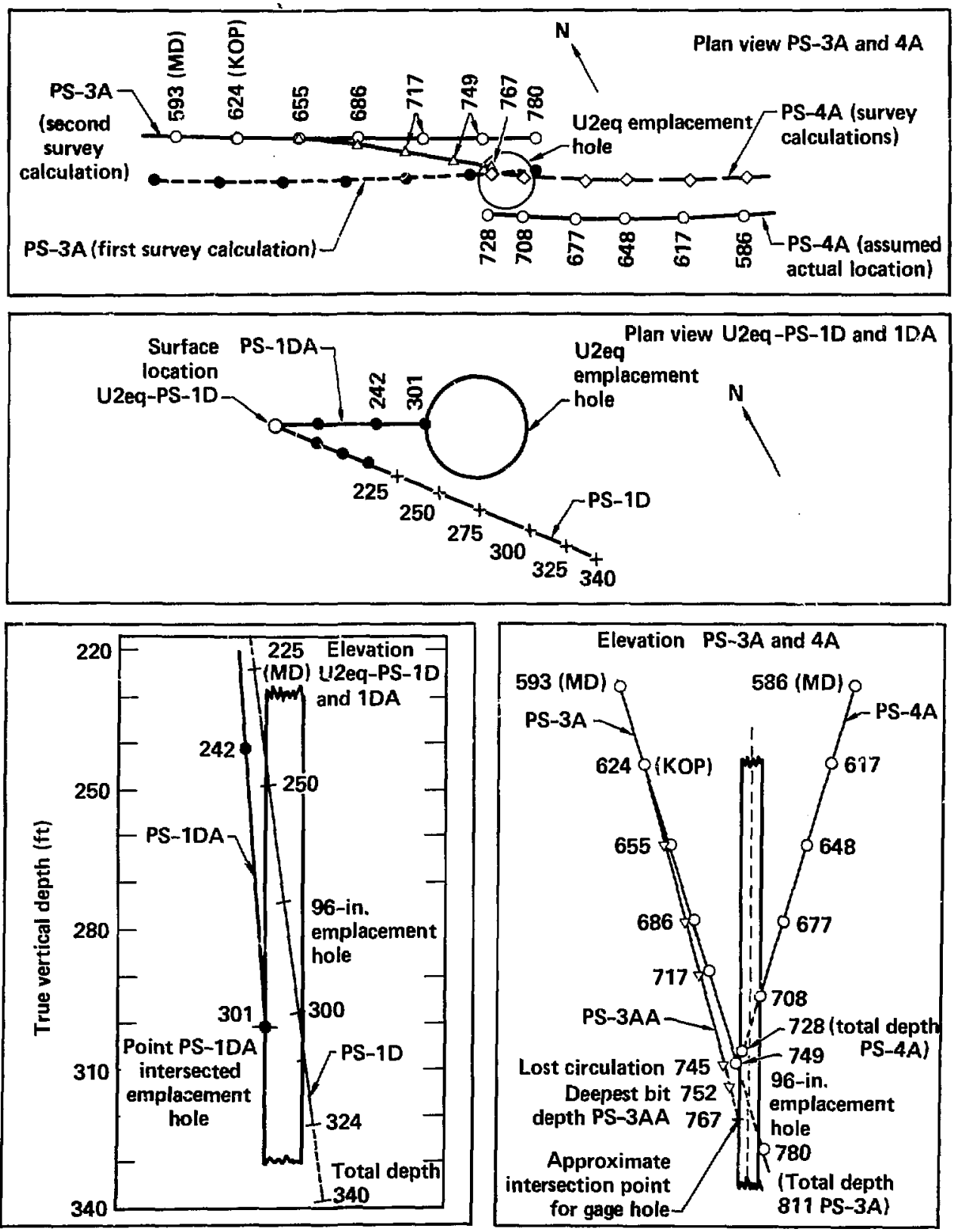

Figure 9. Photographic postshot holes. 


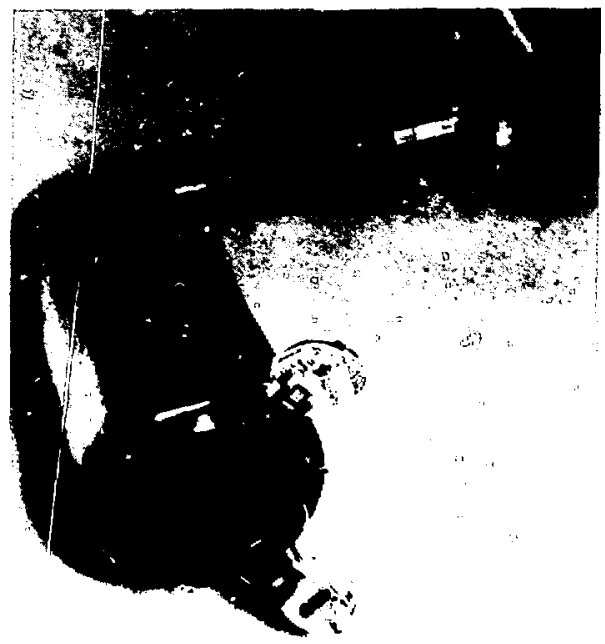

Figure 10. Camera for downhole photography.

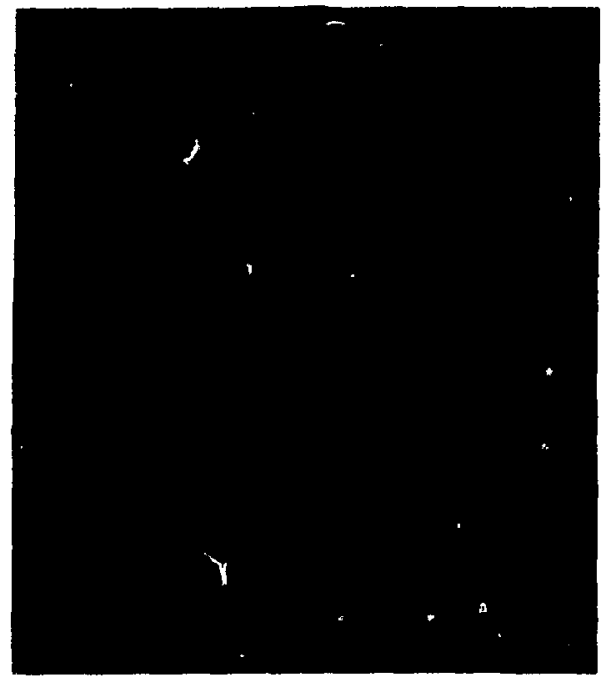

Figure 11. Upper vacuum demand valve.
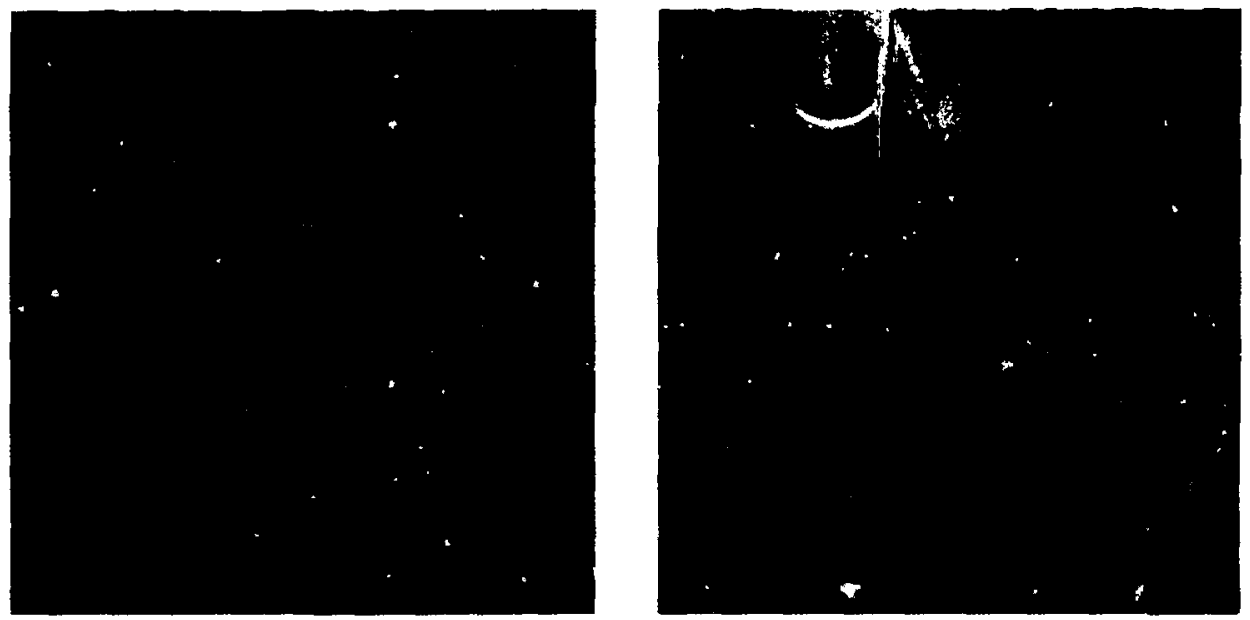

Figure 12. (a) Top of emplacement hole enlargement at $655 \mathrm{ft}$, and (b) cable snarl and bottom of hole enlargement at $805 \mathrm{ft}$. 

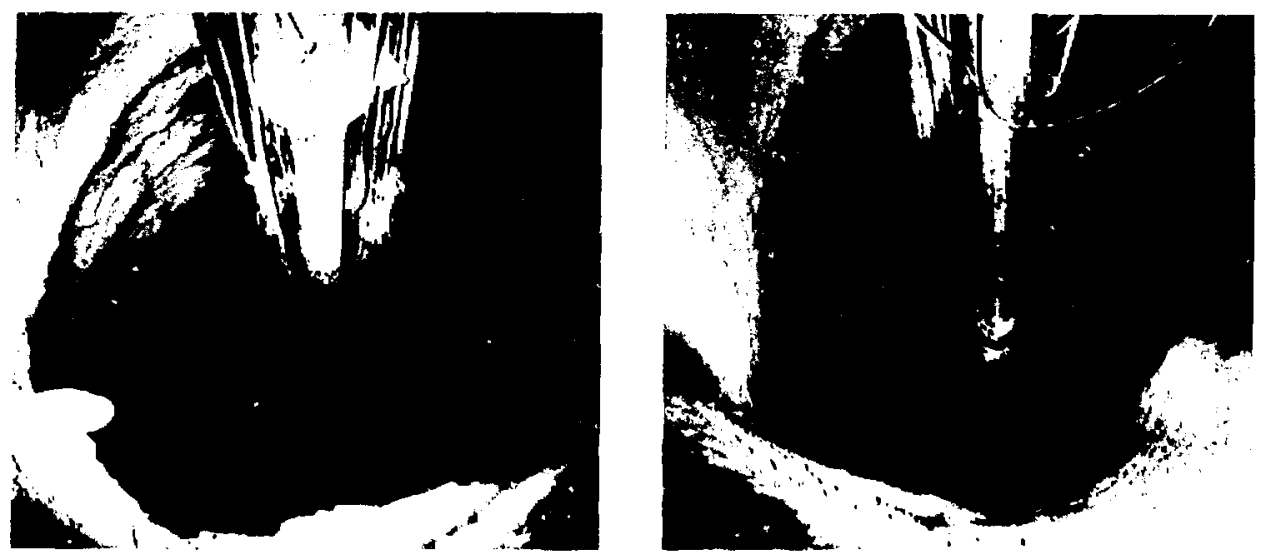

Figure 13. Enlarged hole (a) below and (b) above stemming platform.

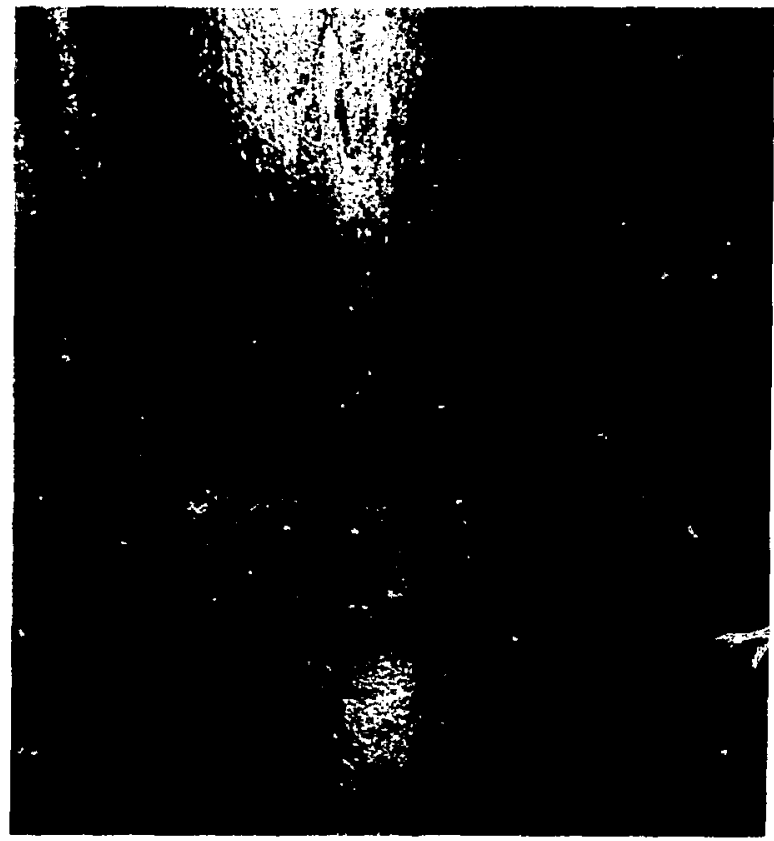

Figure 14. Top of plug at as-built depth (685 ft). 

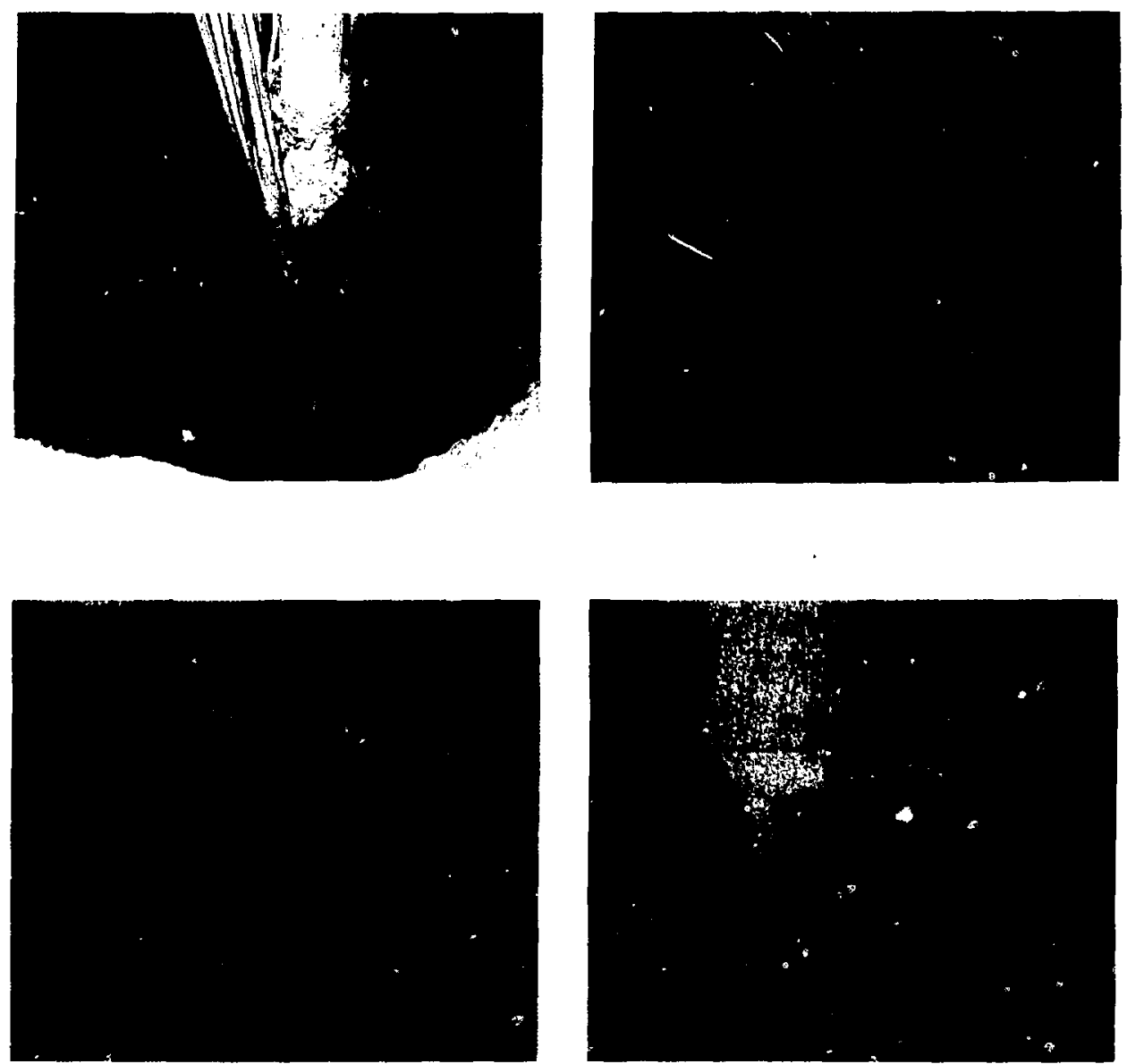

Figure 15. (a) Remains of stemming platic:.: from above, (b) upper portion of stemming platform core supported by cables, (c) remains of stemming platform around $695 \mathrm{ft}$, and (d) plug support ring and stemming platform core at $699 \mathrm{ft}$. 


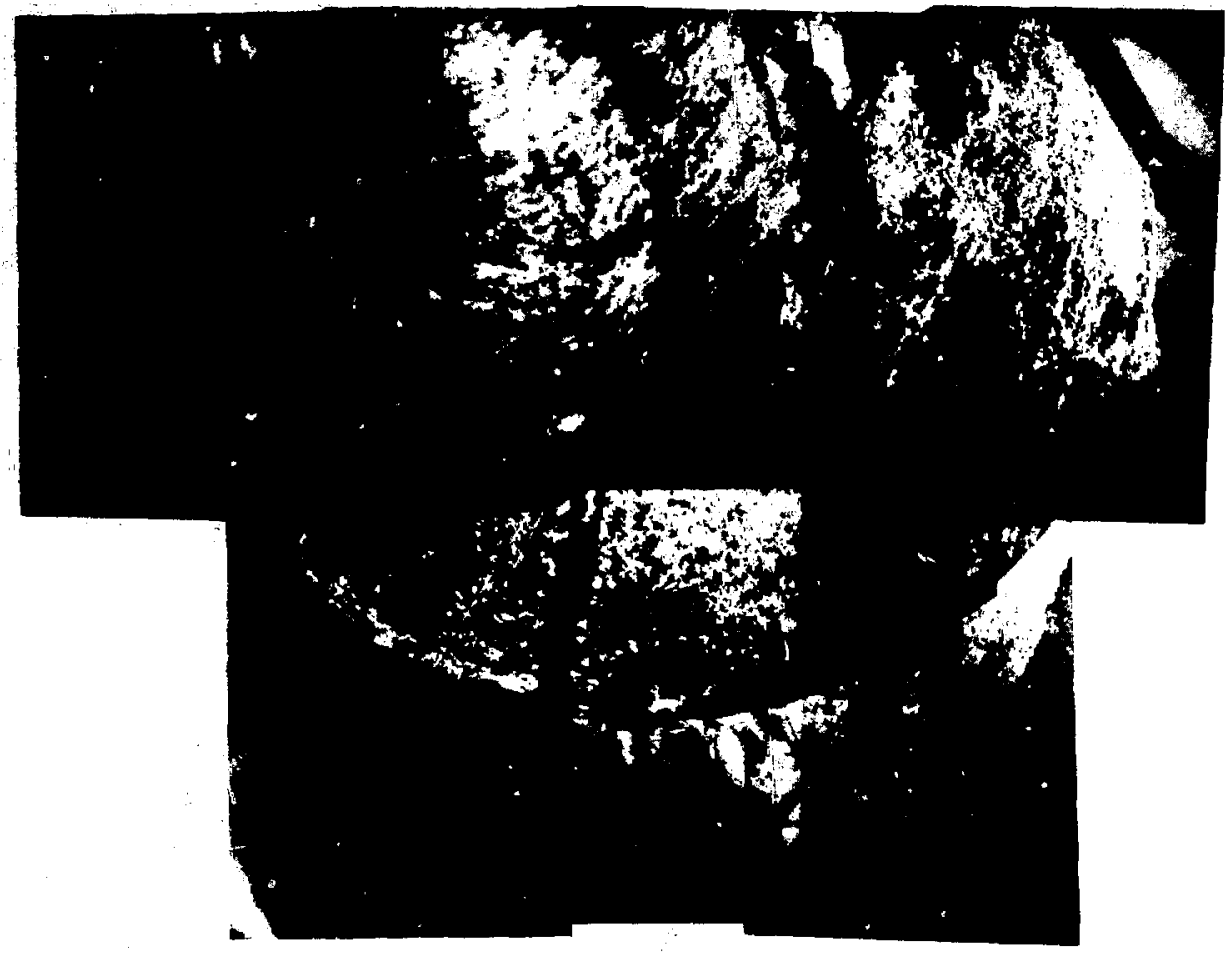

Figure 16. Mosaic of seven photographs (opposite side) showing remains of lower portions of stemming platform.

Figure 17. Large cable snarl near $780 \mathrm{ft}$ resulting from cable breakage and stemming fall.

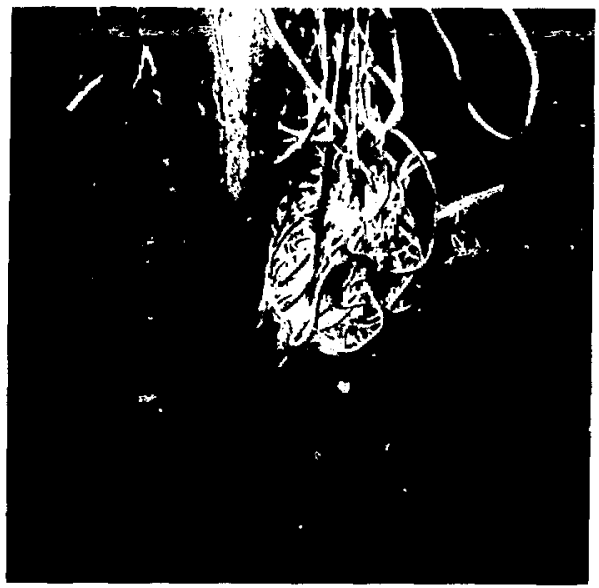



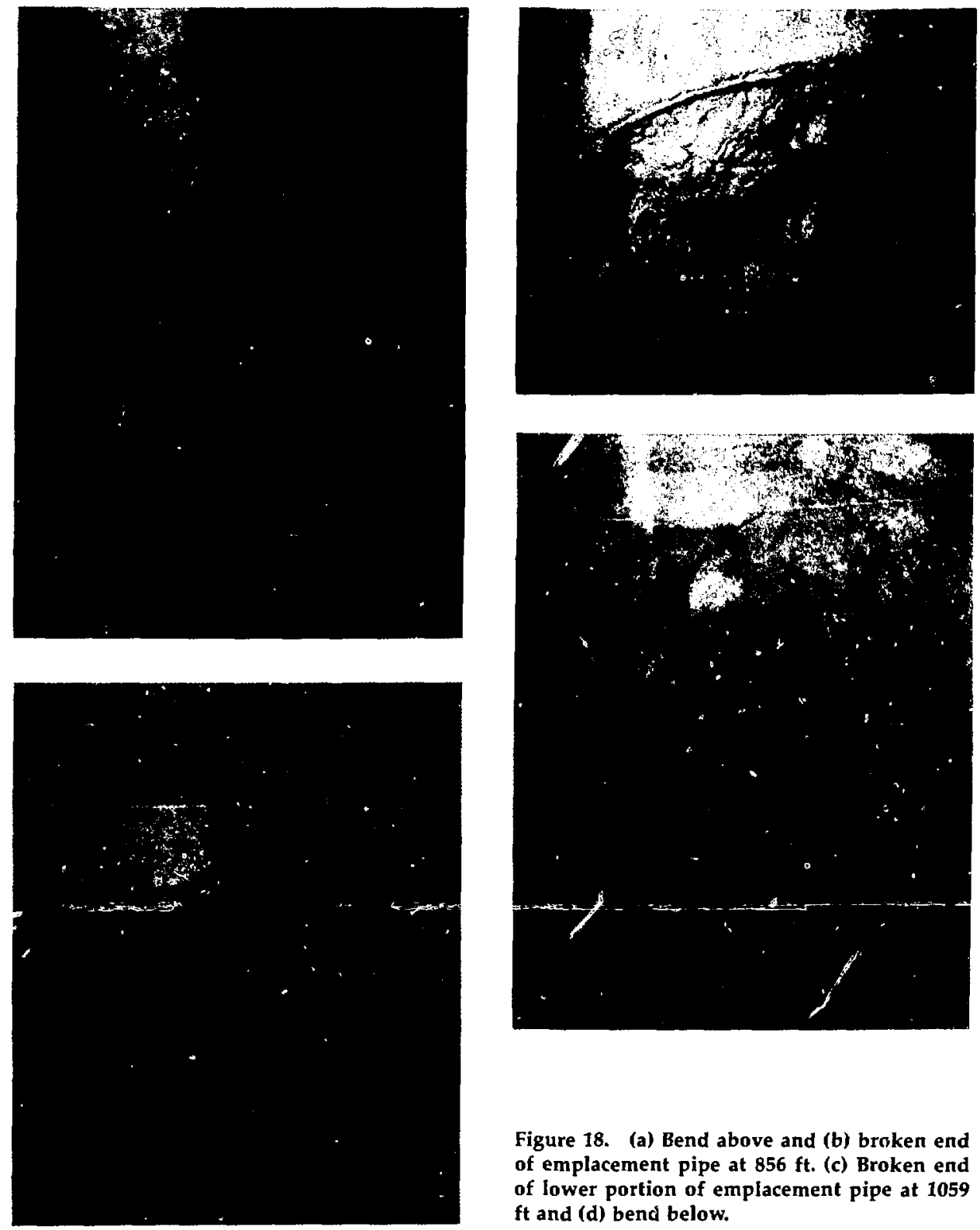

Figure 18. (a) Bend above and (b) broken end of emplacement pipe at $856 \mathrm{ft}$. (c) Broken end of lower portion of emplacement pipe at 1059 ft and (d) bend below. 


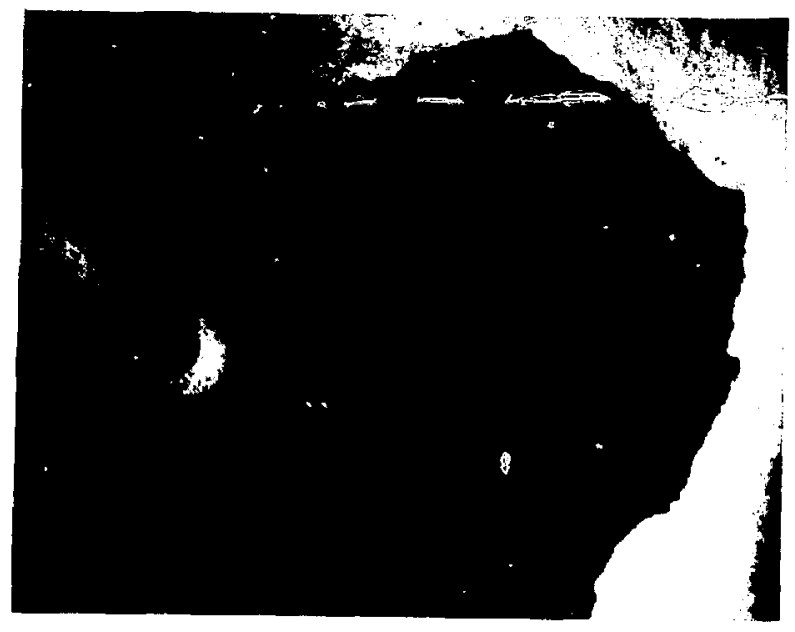

Figure 19. Top of chimney at about $1135 \mathrm{ft}$.

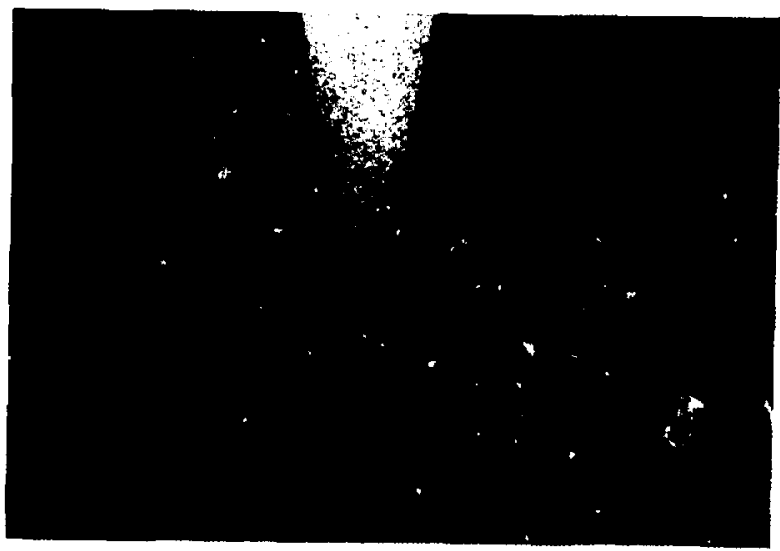

Figure 20. Fallen emplacement pipe disappearing into rubble at $1170 \mathrm{ft}$. 


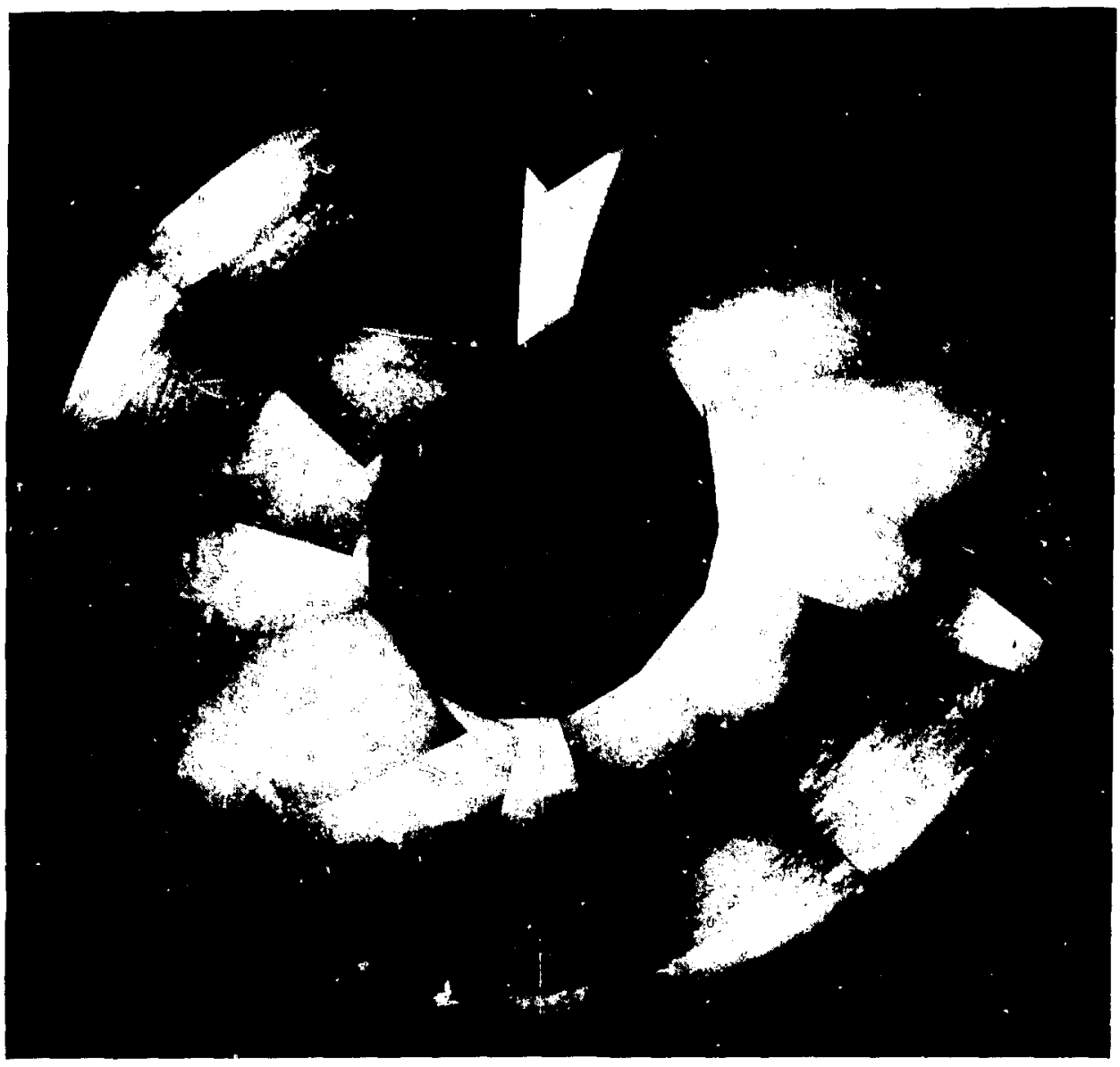

Figure 21. Mosaic of 11 photographs of chimney, looking down at 45 deg from vertical. 


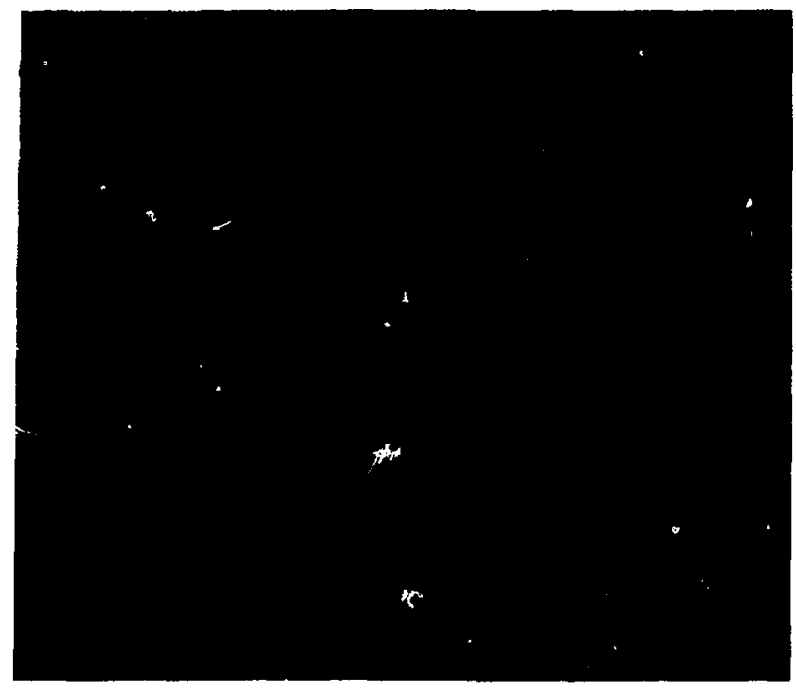

Figure 22. View looking up from $310 \mathrm{ft}$, showing gage emplacement hole and cable that supports camera.

\section{Reviews}

\section{Emplacement and Stemming}

The Riola Event was emplaced and stemmed according to the plan presented to the Containment Evaluation Panel. The only modification was use of an increased thickness of fines layers to ensure the covering of fanouts. Coal-tar epoxy (CTE) for the stemming platform plug was pumped through a tremie pipe (a pipe for pumping fluids, grout, CTE, etc.) to the plug elevation, while gravel was poured into the hole. This was standard procedure for emplacing plugs at depths of more than $500 \mathrm{ft}$. A diagram of the ster ming and emplacement is shown in Fig. 23. Plug and gas-block locations are shown in Fig. 24. Figure 25 shows the downhole gas-sampling installation. Table 4 is a summary of the stemming, and Table 5 shows stemming balance information. The results of the QA samples for the Riola stemming platform are contained in Table 6, and Fig. 26 shows the temperature profile provided by a thermistor at a depth of $695 \mathrm{ft}$ (well within the plug) and about 3 in. from the emplacement pipe, where it also detected thermal effects from the emplacement pipe grouting. "Emplacement and
Containment Report for U2eq"7 contains more detail and documentation on the emplacement and stemming.

Shortly after the event, H. E. Watling, then group leader for containment in the Mechanical Engineering Department, reviewed Riola design and construction. He states:

"I have reviewed the engineering design and execution of the Riola emplacement and stemming and can find nothing that explains clearly the postevent phenomena which were observed. The areas which I have reviewed include the design, emplacement, and operation of the gas sampling system, ihe special measurements, the emplacment hardware, the cables and gas blocks, and the stemming and plastic plugs. $J$ have also reviewed the QA documentation and deviations which occurred. While there were changes and deviations in the field, they were minor in nature and were not, in my opinion, connected to any postevent phenomena. The entire operation appears to have been conducted in a 


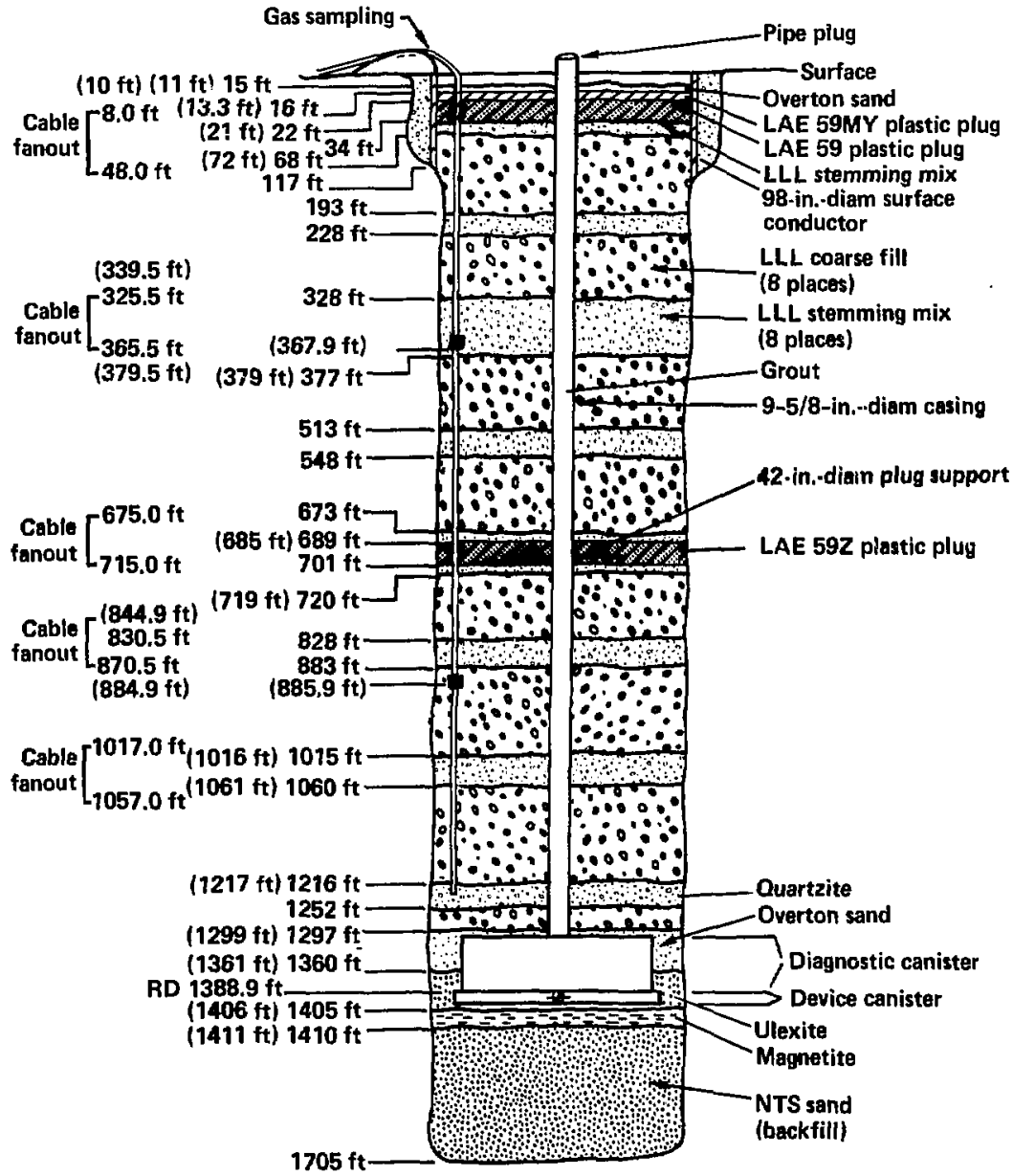

Figure 23. Riola stemming and emplacement for U2eq.

proper manner using good design practices and sound engineering judg :tent." An independent review was subsequently made by Alan B. Casamajor. His conclusions and recommendations are quoted below?:

"Based upon my examination of the records of the Riola Event, I can find no discrepancies between the specifications, procedures, and normal practices for a containment system and what was actually done in the field. All of the people involved with this program appear competent and conscientious. Where I was able to make an independent check of their work, I found that everything was in order.

"Specifications that have been formalized are clear, performable, and appear sufficient for their specific tasks. There is a need to do some additional work in the area of defining the acceptance criteria for an emplaced plug. This includes both documenting existing data, and obtaining and documenting additional data in several areas." 
Cables

Top of hole

Field gas block 15

Factory gas block 48

No gas block

Total

$\frac{2}{65}$

Top plug

Field gas block 15

Factory gas block 48

Tota!

$\overline{63}$

Bottom plug

Field gas block 12

Factory gas block $\frac{43}{55}$
Total

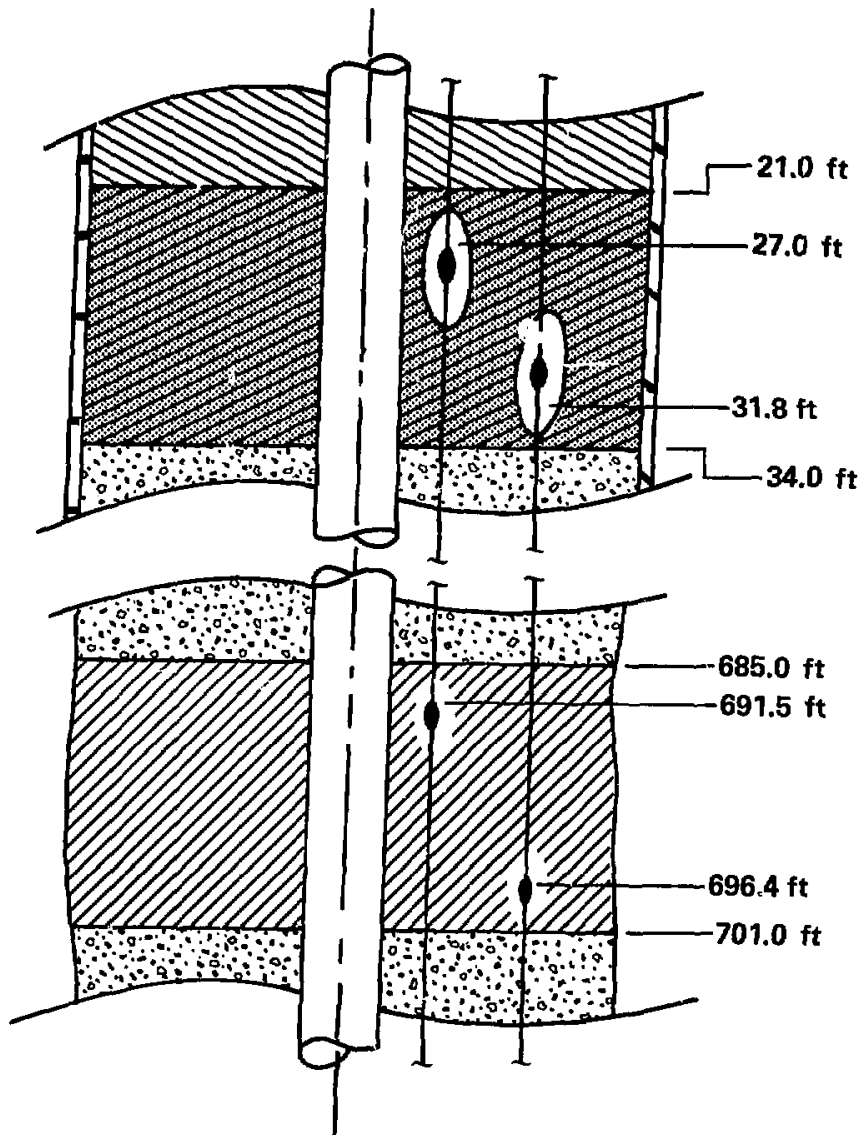

Figure 24. Riola plugs and gas blocks. 


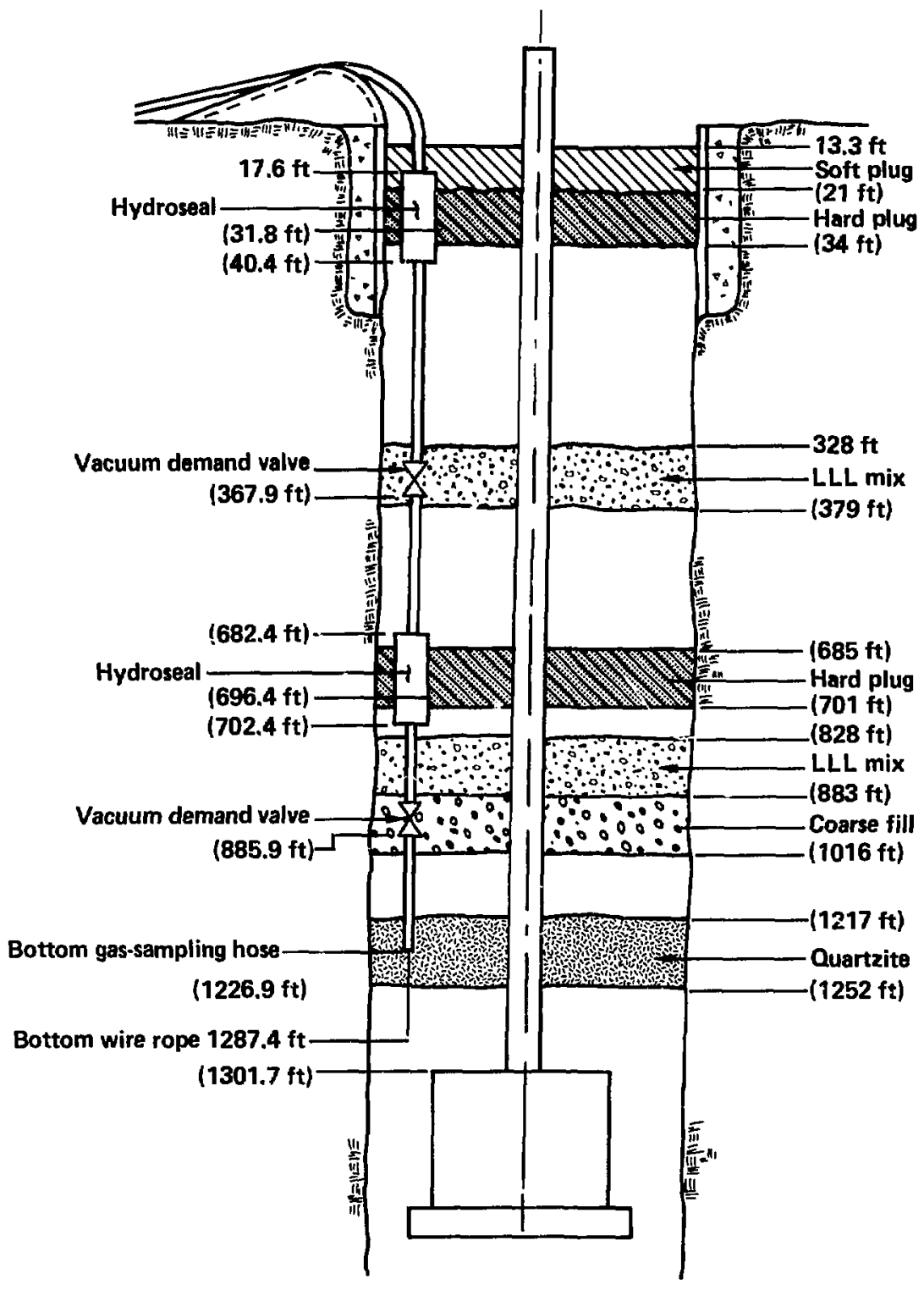

Figure 25. Downhole gas sampling. 
Table 4. Riola material balance.

Title Material balance U2eq

Date 9-22-60

\begin{tabular}{|c|c|c|c|c|c|c|c|c|c|}
\hline & & Plan & & & & & As-built & & \\
\hline $\begin{array}{l}\text { DH } \\
\text { elev }\end{array}$ & Lin & $Y \mathbf{d}^{\mathbf{3}}$ & Tons & Material & Elev & Lin & Tons & $\begin{array}{l}\text { Density } \\
\mid \mathrm{lb} / \mathrm{fI}^{3}\end{array}$ & Remarks \\
\hline \multicolumn{10}{|l|}{1411} \\
\hline \multirow[t]{3}{*}{1406} & 5 & 9.8 & 23.0 & Mugnetite & & & & & \\
\hline & & & & Adjustmen! & & & (9 K on SG) & & \\
\hline & & & & Total Magnetite & 1406 & 5 & $\mathbf{2 3 . 0}$ & 175.0 & Cale \\
\hline \multirow[t]{3}{*}{1360} & 46 & 34.0 & 41.3 & Ulexite & & & & & \\
\hline & & -0.8 & -0.9 & Adjustment -1 it & & & & & \\
\hline & & 33.2 & 40.4 & Tolal ulexite & 1361 & 45 & 47.9 & 106.6 & $\begin{array}{l}\text { SS } 1364 \\
42.7 \mathrm{~T}\end{array}$ \\
\hline \multirow[t]{3}{*}{1247} & 6.3 & $20+.3$ & 140.43 & Overfon sand & & & & & $\begin{array}{l}\text { SS } 1364 \\
44.6 \mathrm{~T}\end{array}$ \\
\hline & & -3.7 & -5.0 & Adjustment - 1 ft & & & & & \\
\hline & & 100.6 & 135.8 & Total Overton sand & 1299 & 62 & 138.1 & 101.7 & (2) 551299 \\
\hline \multirow[t]{3}{*}{1252} & 45 & 85.3 & 103.7 & LLNL coarse & & & & & \\
\hline & & +4.5 & +5.4 & Adjustment $+2 \mathrm{ft}$ & & & & & \\
\hline & & 89.8 & 109.1 & Tolal LLNL coarse & 1252 & 47 & 102.0 & 84.1 & "D" 1252 \\
\hline \multirow[t]{3}{*}{1216} & 36 & 66.9 & 86.7 & Quartzite & & & & & \\
\hline & & -1.9 & -2.4 & Adjustment - 1 ft & & & & & \\
\hline & & 65.0 & 84.3 & Total Quartzite & 1217 & 35 & 85.5 & 97.3 & "D" 1217 \\
\hline \multirow[t]{3}{*}{1060} & 56 & 295.6 & 359.2 & LUNL coarse & & & & & \\
\hline & & & & Adjustment 0 fi & & & & & \\
\hline & & & & Total LLNL coarse & 1061 & 56 & 346,0 & 86.7 & "D" 1061 \\
\hline \multirow[t]{3}{*}{1015} & 45 & 85.1 & 108.0 & LLNL mix & & & & & \\
\hline & & & & Adjustment 0 ft & & & & & \\
\hline & & & & Total LLNL mix & 1016 & 45 & 109.3 & 95.1 & "D" 1016 \\
\hline \multirow[t]{3}{*}{883} & 132 & 255.5 & 310.4 & LLNL coarse & & & & & \\
\hline & & +1.9 & +2.3 & Adjustment +1 ft & & & & & \\
\hline & & 257.4 & 312.7 & Total LLNL coarse & 883 & 133 & 307.7 & 88.6 & "D" 883 \\
\hline \multirow[t]{3}{*}{828} & 55 & 105.29 & 133.6 & LLNL mix & & & & & \\
\hline & & & & Adjustment 0 ft & & & & & \\
\hline & & & & Total LLNL mix & 828 & 55 & 132.8 & 93.4 & $" D " 828$ \\
\hline \multirow[t]{3}{*}{720} & 108 & 209.0 & 253.8 & LLNL coarse & & & & & \\
\hline & & +1.9 & +2.3 & Adjustment + $1 \mathrm{ft}$ & & & & & \\
\hline & & 210.9 & 256.1 & Tolal LLNL coarse & 719 & 109 & 256.1 & 90.0 & $\begin{array}{l}\text { (2) SS } 720 \\
\text { " } 0 \text { " } 720\end{array}$ \\
\hline \multirow[t]{3}{*}{701} & 19 & 36.7 & 46.6 & LLNL mix & & & & & \\
\hline & & -1.9 & -2.4 & Adjustment -1 ft & & & & & \\
\hline & & 34.8 & $\$ 4.2$ & Tatal LLNL mix & 701 & 18 & 49.5 & 105.2 & Tag 701 \\
\hline \multirow[t]{3}{*}{689} & 12 & & & LAE 592 plug & & & & & \\
\hline & & & & Adjustmenl $4 \mathrm{ft}$ & & & & & \\
\hline & & & & Total LAE $59 Z$ plug & 685 & 16 & & & Tag 685 \\
\hline \multirow[t]{3}{*}{673} & 10 & $\mathbf{3 0 . 4}$ & 38.5 & LLNL mix & & & & & \\
\hline & & --7.6 & -9.6 & Adjustment $-4 \mathrm{ft}$ & & & & & \\
\hline & & 22.8 & 28.9 & Total LLNL mix & 673 & 12 & 29.3 & 95.3 & "D" 673 \\
\hline \multirow[t]{2}{*}{548} & 125 & 237.6 & 288.7 & LLNL coarse & & & & & \\
\hline & & & & $\begin{array}{l}\text { Adjustment } 0 \text { fi } \\
\text { Total LLNL coarse }\end{array}$ & 548 & 125 & 296.0 & 92.3 & "D" 548 \\
\hline \multirow[t]{3}{*}{513} & 35 & 66.4 & 84.3 & LLNL mix & 340 & $1<0$ & 290.0 & 92.3 & $D .348$ \\
\hline & & & & Adjustment 0 ft & & & & & \\
\hline & & & & Tolal LLNL mix & 513 & 35 & 91.8 & 102.4 & $D^{\prime \prime} 513$ \\
\hline
\end{tabular}




\begin{tabular}{|c|c|c|c|c|c|c|c|c|c|}
\hline \multicolumn{8}{|c|}{ Title Material balance U2eq } & \multirow[t]{2}{*}{ By $\underline{\mathbf{R G H}}$} & \multirow[t]{2}{*}{ Date 9-22-80 } \\
\hline \multicolumn{4}{|c|}{ Plan } & & \multicolumn{3}{|c|}{ As-built } & & \\
\hline $\begin{array}{l}\mathrm{DH} \\
\text { elev }\end{array}$ & Lin & $\mathbf{Y d}^{3}$ & Tons & Material & Elev & $\begin{array}{l}\text { Lin } \\
\text { fl }\end{array}$ & Tons & $\begin{array}{c}\text { Density } \\
\text { lb/ft }\end{array}$ & Remarks \\
\hline \multirow[t]{3}{*}{377} & 136 & 259.4 & 315.0 & LLNL coarse & & & & & \\
\hline & & -3.8 & -4.6 & Adjustment $-2 \mathrm{ft}$ & & & & & \\
\hline & & 255.6 & 310.4 & Tntal LLNL coarse & 379 & 135 & 318.9 & 92,4 & "D" 378 \\
\hline \multirow[t]{3}{*}{328} & 49 & 94.2 & 119.5 & LLNL mix & & & & & Tag 379 \\
\hline & & +3.9 & +4.8 & Adjustment $+2 \mathrm{ft}$ & & & & & \\
\hline & & 98.0 & 124.3 & Total LLNL mix & 328 & 51 & 117.4 & 88.7 & "D" 328 \\
\hline \multirow[t]{2}{*}{78} & 100 & 144.9 & 236.8 & LLNL coarst: & & & & & \\
\hline & & & & $\begin{array}{l}\text { Adjustment } 0 \text { ft } \\
\text { rotal LLNL cosrse }\end{array}$ & 228 & 100 & 243.6 & 92.6 & "D" 228 \\
\hline \multirow[t]{3}{*}{193} & 35 & 69.5 & 83.2 & LLNL mix & & & & & \\
\hline & & & & Adjustment $0 \mathrm{ft}$ & & & & & \\
\hline & & & & Total LLNL mix & 193 & 35 & 84.7 & 90.3 & "L" 193 \\
\hline \multirow[t]{3}{*}{68} & 125 & 247.6 & 300.8 & LLNL coarse & & & & & \\
\hline & & -7.6 & -9.3 & Adjustment $-4 \mathrm{ft}$ & & & & & \\
\hline & & 240.0 & 291.5 & Total LLNL coarse & 72 & 121 & 266.6 & 82.3 & "D" 72 \\
\hline \multirow[t]{3}{*}{34} & 34 & 64.9 & 82.4 & LLNL mix & & & & & \\
\hline & & & & Adjustment 0 ft & & & & & \\
\hline & & & & Total LLNL mix & 34 & 38 & B6.8 & 99.0 & $\operatorname{Tag} 34$ \\
\hline \multirow[t]{3}{*}{22} & 12 & & & LAE 59 plug & & & & & \\
\hline & & & & Adjustment +1 ft & & & & & \\
\hline & & & & Total plug & 21 & 13 & & & Tag 21 \\
\hline $\begin{array}{l}\text { DH } \\
\text { elev }\end{array}$ & $\operatorname{lin}_{\mathrm{ft}}$ & $\mathbf{F t}^{3}$ & Tons & Material & Elev & Lin & Tons & $\begin{array}{l}\text { Density } \\
{\text { lb } / \mathbf{f t}^{\mathbf{3}}}\end{array}$ & Remarks \\
\hline \multirow[t]{3}{*}{16} & 6 & - & - & LAE-59MY plug & & & & & \\
\hline & & & & Adjustment & & & & & \\
\hline & & & & Total plug & 13.3 & 7.7 & - & - & Tag 13.3 \\
\hline \multirow[t]{3}{*}{15} & 1 & 1.9 & 2.6 & Overion sand & & & & & \\
\hline & & & & Adjustment +1.3 ft & & & & & \\
\hline & & & & Tota: Overton sand & 11 & 2.3 & - & - & Tag 11 \\
\hline
\end{tabular}

Table 5. Stemming material U2eq.

\begin{tabular}{|c|c|c|c|c|}
\hline Materi:̈l & Plan & As-built & Tons \pm & $\%$ \\
\hline Magnatite & 23.0 & 23.0 & 0 & 0 \\
\hline Ulexite & 40.4 & 47.9 & +7.5 & +18.5 \\
\hline Overton sand & 135.8 & 138.1 & +2.3 & +1.7 \\
\hline Quartzite & 84.3 & 85.5 & +1.2 & +1.4 \\
\hline LLNL coarse & 2164.5 & 2136.9 & -27.6 & -1.3 \\
\hline LLNL mix & 693.9 & 701.6 & +7.7 & +1.1 \\
\hline Total & 3141.9 & 3133.0 & -8.9 & -0.3 \\
\hline \multicolumn{5}{|c|}{$\begin{array}{l}\text { 6.2\% Flyash emplaced with LLNL mix. } \\
\text { LLNL mix to LLNL coarse } 33 \% \text {. }\end{array}$} \\
\hline
\end{tabular}


Table 6. Assurance tests.

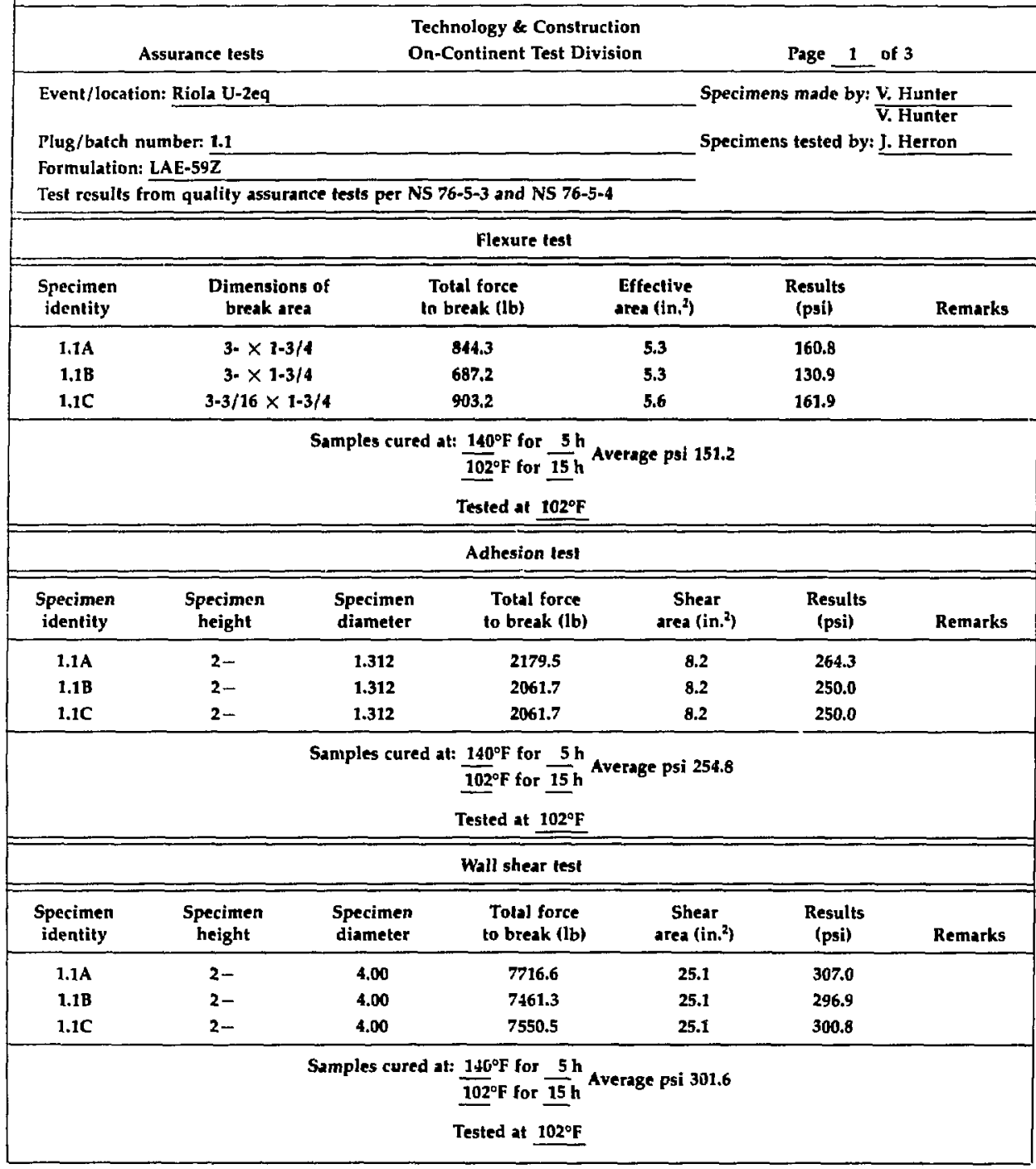




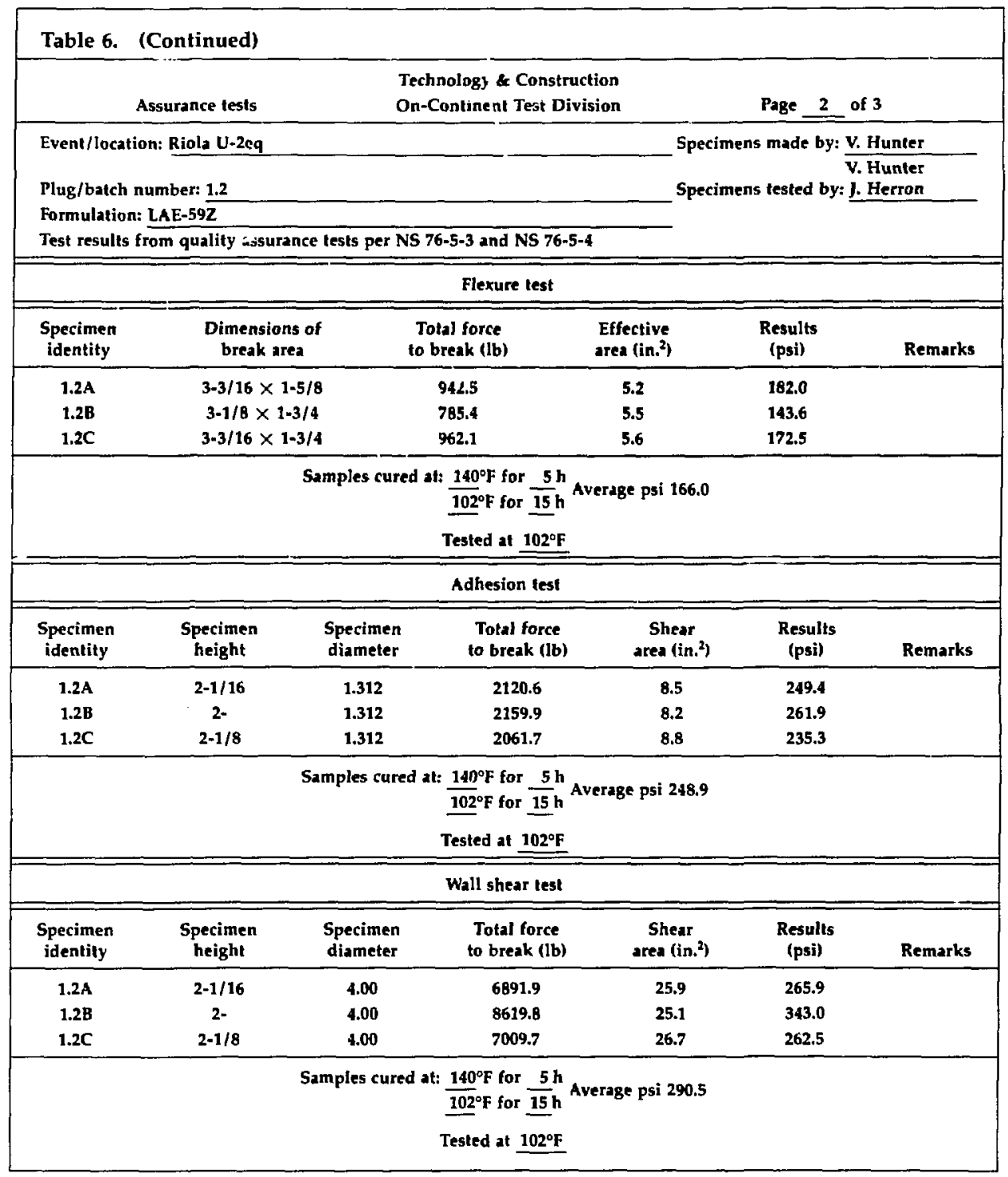




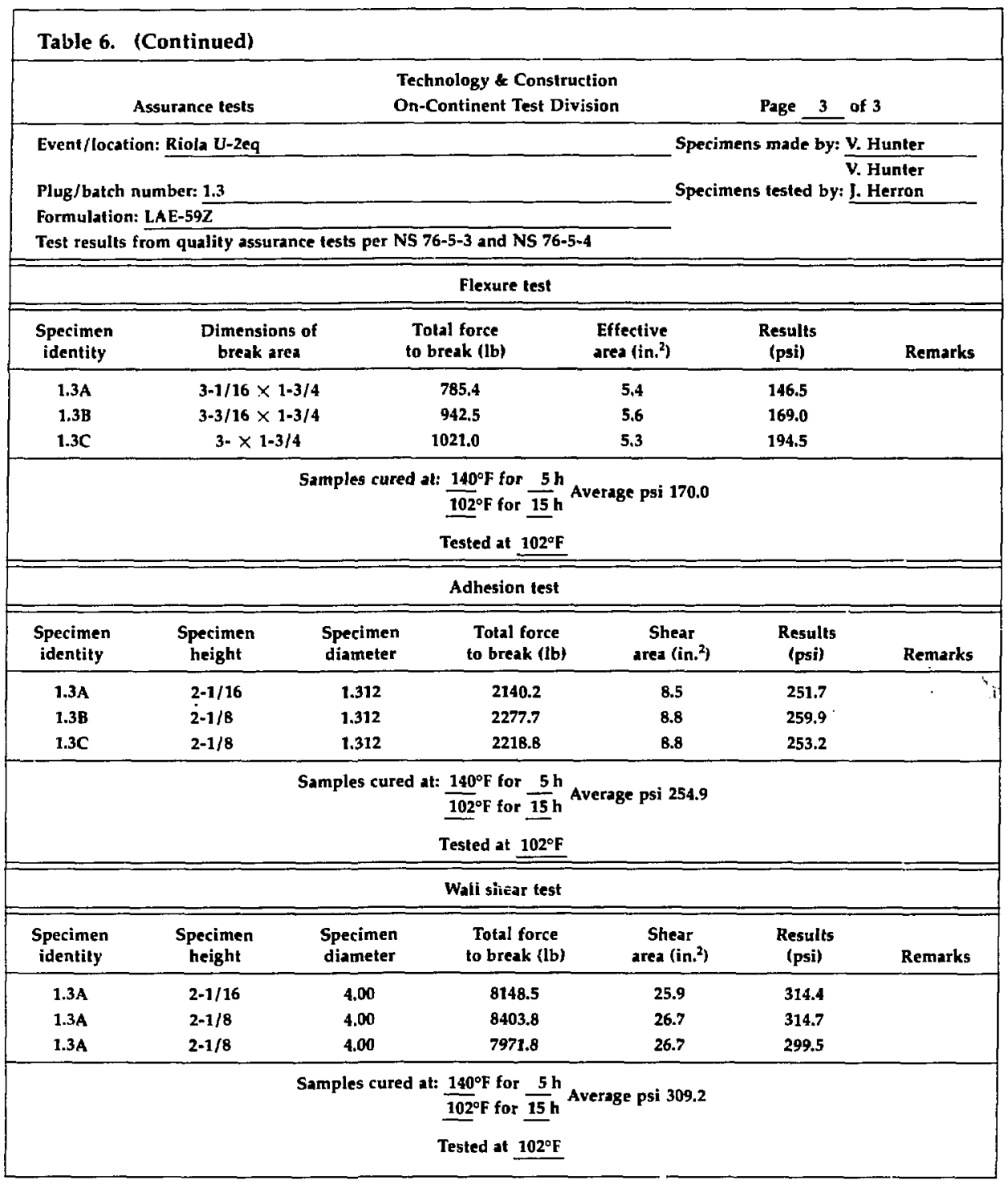




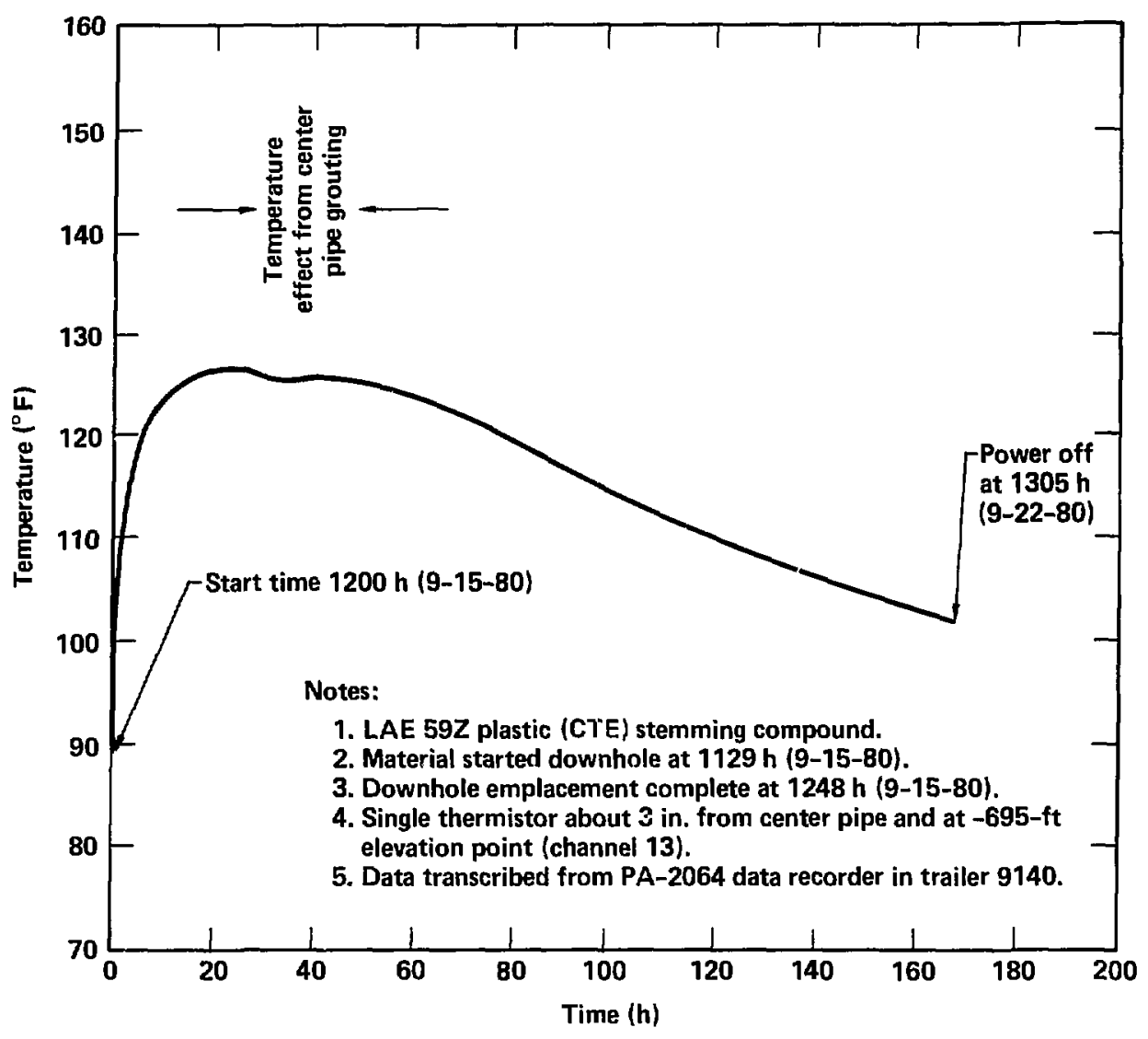

Figure 26. Temperature history of stemming platform.

\section{Studies}

\section{Radiation Release}

\section{Study 1}

The official value for the release of radioactive fission products from Riola is $3123.5 \mathrm{Ci}$. Because of wind-velocity effects and remote airmonitoring system (RAMS) data recording and interpolation, this value is considered to represent an upper limit to the amount of material released, and $a$ value of $1624 \mathrm{Ci}$ is thought to be more cor- rect. In adtition a seepage of tritium estimated at $2775 \mathrm{Cl}$ occured in the five months following the event. Further details are contained in "The Riola incident-Prompt Release Results."10

\section{Study 2}

Release dispersion data were collected by the Environmental Protection Agency's (EPA's) Environmental Monitoring Systems Laboratory in Las Vegas (EMSL-Las Vegas). Radioxenon was reported otfsite at Lathrop Wells, Nevada, while 
onsite radioxenon was detected at BJY, at Areas 12,15 , and 51 , and by aircraft over SGZ. No radioxenon was reported at Mercury or Area 400, however, both of which are on the path between the release and Lathrop Wells. Results of the compressed air samples are shown in Table 7. The interim report by the EMSL-Las Vegas contains further detail. ${ }^{11}$

\section{Study 3}

REECo monitors radioactivity in the general onsite environnent for the Department of Energy (DOE). Air-sampling stations are located at sites throughout the NTS. Gross beta analysis has provided the most information on the majority of test site samples, permits rapid determination of trends in gross radioactivity, and has a low detection limit.

An examination of the data for 1980 showed that a number of air-sampling stations collected a significantly larger amount of gross beta radioactivity than background for the week in which the Riola release occurred. These stations are in Areas 3, 5, and 6; Fig. 27 shows their locations. The "Environmental Surveillance Report for the Nevada Test Site" contains detailed information. ${ }^{12}$

\section{Study 4}

Release dispersion calculations were performed by Paul Gudiksen and George Greenly ${ }^{13}$ of the Atmospheric and Geophysical Sciences Division of LLNL. To do these calculations, they employed two three-dimensional atmospheric transport and dispersion codes, using source data supplied by K. Oswald and meteorological data provided by the Weather Service Nuclear Support Office at the NTS. Their calculations showed, because of the topography surrounding the Riola event site, that downslope surface flows during the night of 25 September provided a generally southward advection of air carrying the ${ }^{135} \mathrm{Xe}$. After sunrise, these flows were destroyed because of heating of the sloped surfaces, causing a reversal to northward upslope flows.

During the first six hours, the xenon gas was transported directly southward, toward Yucca Flat (UCC), where the Skull and Half Pint mountain ranges directed the radioactivity toward the Jackass $\mathrm{Fl}_{\mathrm{i} . \mathrm{s}}$ (JAC) area (where no activity was detected). The activity continued in a southwesterly direction, reaching an area immediately north of the Lathrop Wells (LAW) sampler location by about $0800 \mathrm{~h}$ PDT on 26 September [Fig. 28(a)]. By

Table 7. Compressed air samples.

\begin{tabular}{|c|c|c|c|c|c|}
\hline \multirow{3}{*}{$\frac{\text { Location }}{\text { Beatty, NV }}$} & \multirow{3}{*}{$\begin{array}{c}\begin{array}{c}\text { Date } \\
\text { collected }\end{array} \\
09 / 26 / 80\end{array}$} & \multirow{2}{*}{\multicolumn{2}{|c|}{$\begin{array}{l}\text { Sampling Period } \\
\text { Date/Time to Date/Time }\end{array}$}} & \multicolumn{2}{|c|}{$\begin{array}{l}\text { Concentration } \\
\left(\mathrm{pCi} / \mathrm{m}^{3}\right)\end{array}$} \\
\hline & & & & \multirow{2}{*}{$\frac{{ }^{133} \times \mathbf{e}}{\text { ND }}$} & \multirow{2}{*}{$\frac{{ }^{135} \mathrm{Xe}}{\mathrm{ND}}$} \\
\hline & & 24/1435 & $26 / 1405$ & & \\
\hline Indian Springs, NV & $09 / 26 / 80$ & $23 / 0945$ & $26 / 1115$ & ND & ND \\
\hline Lathrop Wells, NV & $09 / 26 / 80$ & $24 / 1150$ & $26 / 1400$ & 34 & 360 \\
\hline Tonopah, NV & $09 / 29 / 80$ & $24 / 1500$ & 29/1305 & ND & ND \\
\hline Rachael, NV & $09 / 29 / 80$ & $25 / 0920$ & 29/1605 & ND & ND \\
\hline Hiko, NV & $0 S / 29 / 80$ & $25 / 1030$ & 29/1715 & ND & ND \\
\hline Area 15, NTS & $09 / 26 / 80$ & $23 / 1350$ & 26/1335 & 7.7 & 64 \\
\hline Area 400, NTS & 09 !26/80 & $24 / 1400$ & $26 / 1230$ & ND & ND \\
\hline Mercury, NTS & $09 / 26 / 80$ & $23 / 1040$ & $26 / 1150$ & ND & ND \\
\hline Area 51, NTS & $09 / 26 / 80$ & 23/1435 & $26 / 1415$ & ND & 12 \\
\hline BJY, NTS & $09 / 26 / 80$ & 23/1135 & 26/1215 & 2,100 & 30,000 \\
\hline Area 12, NTS & $09 / 26 / 80$ & 23/1205 & $26 / 1300$ & 34 & 280 \\
\hline $\begin{array}{l}\text { Aircraft sample No. } 1 \\
\text { collected over SGZ }\end{array}$ & $09 / 26 / 80$ & $26 / 1132$ & $26 / 1143$ & 150 & 1,300 \\
\hline $\begin{array}{l}\text { Aircraft sample No. } 2 \\
\text { collected along } \\
\text { Hwy } 95 \text { from Mercury } \\
\text { to NECO }\end{array}$ & $09 / 26 / 80$ & 24/1421 & $26 / 1433$ & ND & ND \\
\hline
\end{tabular}




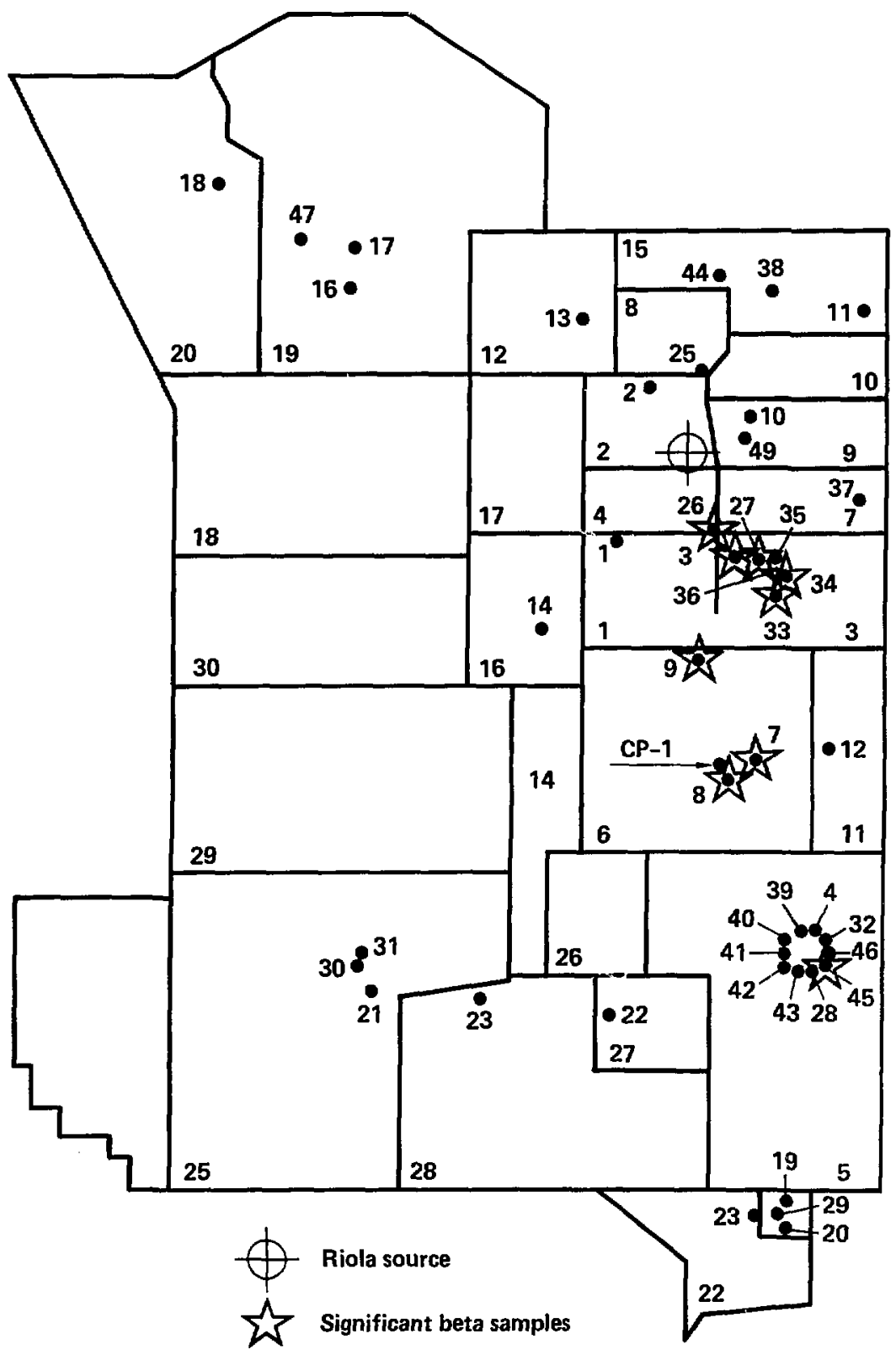

Figure 27. NTS air-sampling stations for environmental surveillance. 


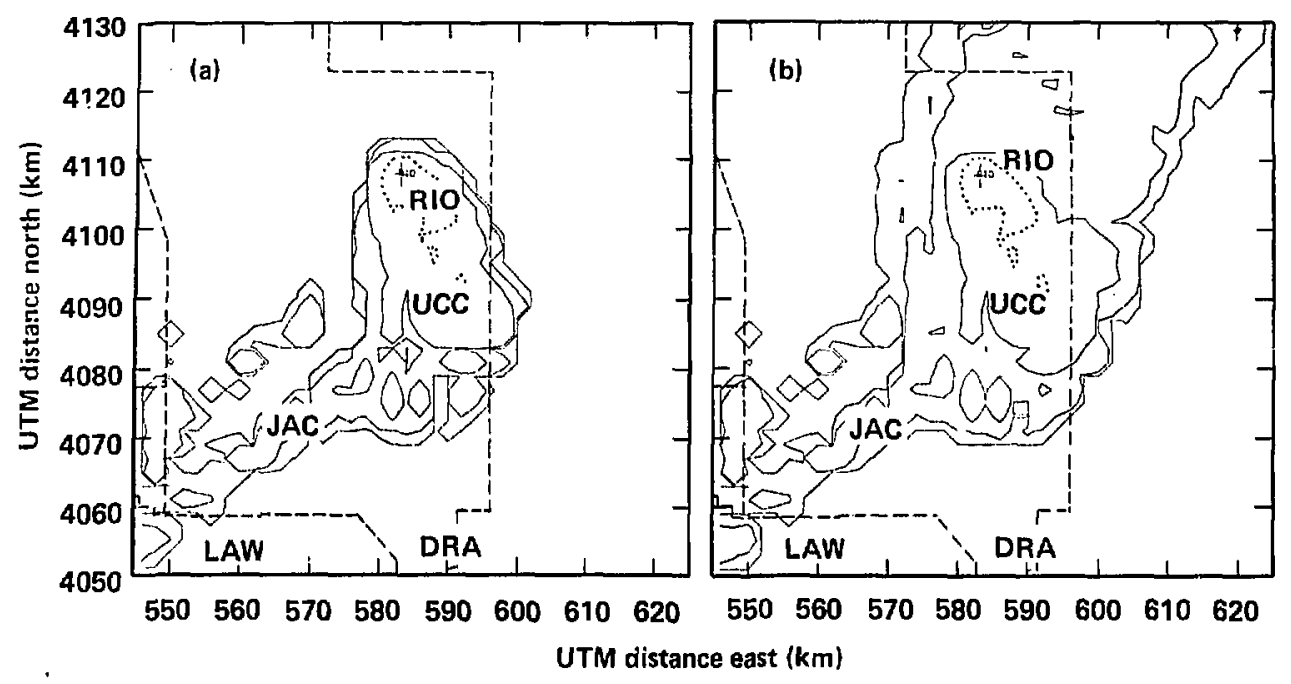

Figure 28. Radiation dispersion calculation (a) morning and (b) afternoon 26 September 1980.

noon, the effects of the daytime upslope resulted in the apparent northerly transport of activity toward the northeast corner of the test site [Fig. $28(b)]$.

\section{Study 5}

"Wind Flow Study-Riola, U2eq"14 describes a release transport study performed by J. $R$. Smith, using surface wind data from the appropriate onsite meteorological data acquisition airsampling stations. Employing a sinuple vector sofution, he developed the path of a marker particle. Tivo pussible paths exist for the near-surface activity to move from Yucca Flat to Frenchman Flat. The wind velncity history indicates that the drainage winds dispersed after $0200 \mathrm{~h}$ on 26 September (Fig. 29).

\section{Plug-Hole Interaction}

"Ground Shock Evaluation of the CTE Plug for the U2eq Riola Event"15 describes a dynamic finite element analysis program in which appropriate soil mechanics equations and criteria were applied for stress analysis of an axisymmetric model. The soil, plug, and stemming material properties used are shown in Table 8 . Figure 30 shows the vertical stress-time history, and Fig. 31 shows the axisymmetric finite element model.

The calculations show the element in the alluvium, along the plug-alluvium interfare noar the bottom of the plug, to be critically stressed ( $25 \%$ greater than a conservative failure criterion). Calculations were also done on a keyway (purposely enlarged zone of the emplacement hole) plug configuration.

The conclusions that resulted from this analytical investigation of Riola plug behavior during ground shock are:

"1. Based on (the) conservative failure criterion for alluvium at the plug depth, it is possible that failure of the Riola plug could have been caused by ground shock.

"2. Even if a material failure due to ground shock did not occur, the alluvium near the plug-soil interface was in a relatively high state of stress due to ground shock plus overburden loadings and reliance on bond and friction at the interface under these conditions is not a strongly desirable design approach.

"3. A small keyway protruding into the soil around the plug can provide a more reliable approach for assuring integral movement of the plug and soil. For 


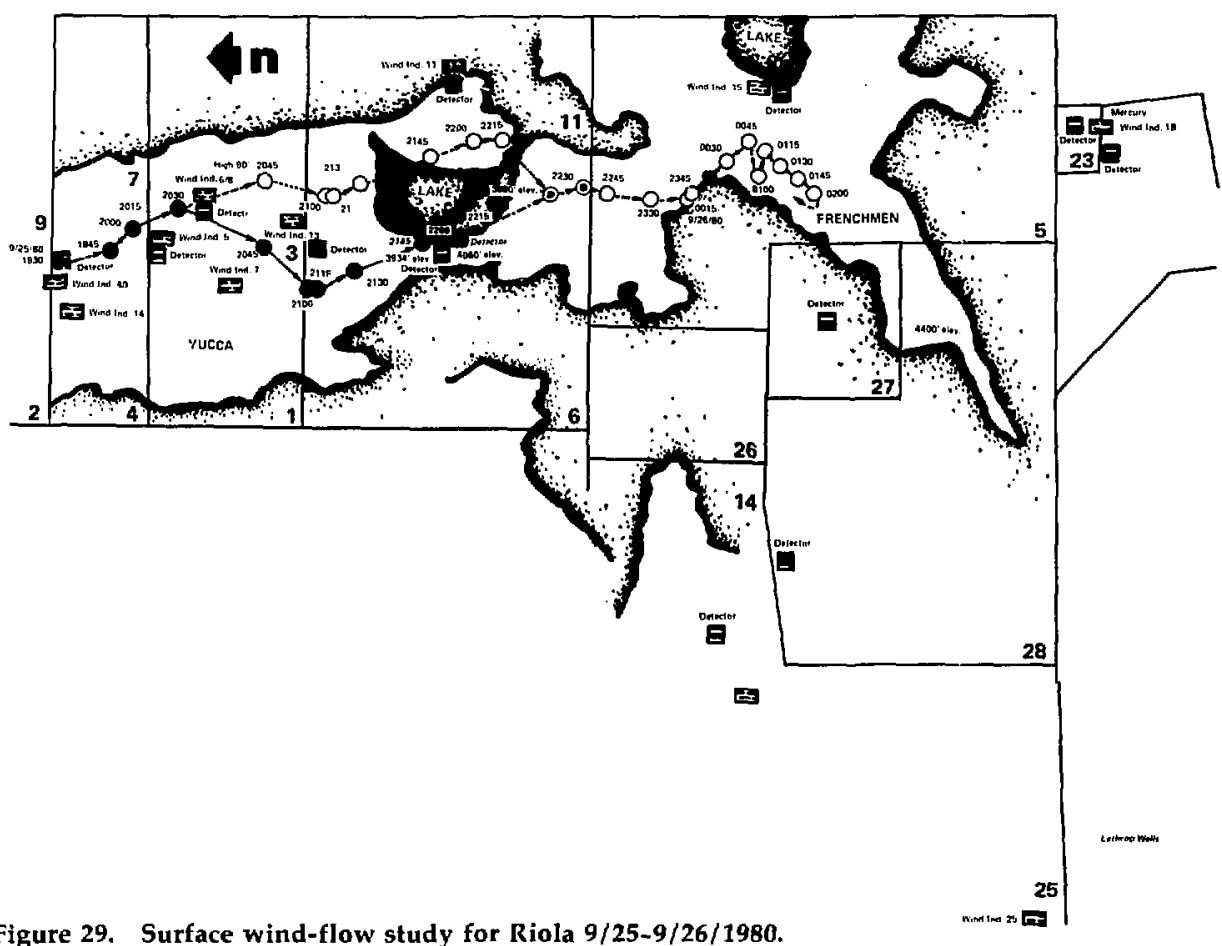

this design, the highly stressed alluvium is confined by the plug material in a manner such that soil failure due to ground shock is very unlikely.

"4. A keyway which is at least two feet in length and six inches deep is adequate to achieve integral movement of the plug with the surrounding soil even if there is no shear capacity of the plug- soil interface. Note that such a key should be located in the upper half of the plug as the highest stressed alluvium is at the bottom face of the key. To provide adequate confinement to this alluvium, it is recommended that the keyway be at least three feet from the bottom face of the plug."

Table 8. Material properties for calculations.

\begin{tabular}{|c|c|c|c|c|}
\hline Material & $\begin{array}{c}\text { Compressory } \\
\text { wave velocity } \\
\text { Cp }_{\text {(fps) }}\end{array}$ & $\begin{array}{c}\text { Young's modulus } \\
\text { E } \\
\text { (psi) }\end{array}$ & $\begin{array}{c}\text { Poisson's ratio } \\
v\end{array}$ & $\begin{array}{c}\text { Weight density } \\
\gamma \\
\text { (pcf) }\end{array}$ \\
\hline Alluvium & 4,500 & 390,000 & 0.3 & 120 \\
\hline CTE & 5,000 & 500,000 & 0.28 & 117 \\
\hline Stemming & 750 & 10,000 & 0.22 & 94 \\
\hline $\begin{array}{l}\text { Grout-filled } \\
\text { pipe (composite) }\end{array}$ & 12,800 & $5,200,000$ & 0.25 & 175 \\
\hline
\end{tabular}




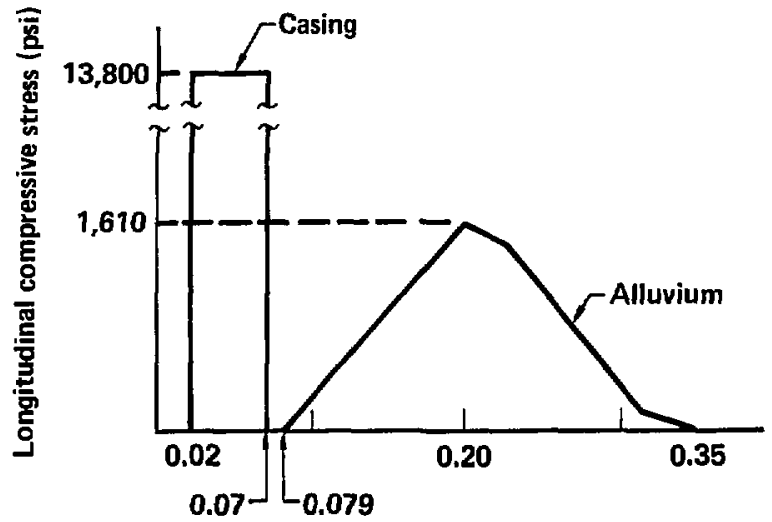

Time (s)

Figure 30. Time history of ground-shock longitudinal compressive stress through emplacement casing and alluvium at CTE plug.

\section{Erosion}

The surface of the remaining portion of the Riola stemming platform appears eroded rather than fractured. In part it has the appearance of a fluted column, with CTE-gravel between the cables being eroded away to form the fluting. Some 1500 tons of stemming passed by the Riola plug location. To gain improved insight into erosional effects, two somewhat qualitative tests were done.

In the first test ${ }^{16}$ gravel was dropped from a height of $16.5 \mathrm{ft}$ onto the end of a cylinder of CTE plug material that was $12 \mathrm{in}$. in diameter and 13-3/4 in. tall. The rate of erosion was about $1 \mathrm{lb}$ of plug material for 44 tons of gravel. Even if we assume terminal velocity for the stemming material and a hundredfold increase in erosion rate, we can only account for about $3 \%$ of the plug material removed.

The second test ${ }^{17}$ consisted of sandblasting some typical materials exposed to erosion by stemming. It showed that plug material is more resistant than tuff and that cable jacket material is more resistant than either. The results of this test and the fluted appearance of the Riola plug core are consistent.

\section{Geophone Signals}

The geophone signal history [Figs. 4(a) and 4(b)] suggests several things. First, it suggests a loss of stemming below the stemming platform, starting slowly at about $1210 \mathrm{~h}$ and continuing until about $1600 \mathrm{~h}$. It also suggests a relative lack of activity in the hole until $1658 \mathrm{~h}$ and a subsequent loss of stemming in the upper part of the hole until $1923 \mathrm{~h}$, when the SGZ RAMS began to detect the release of radioactivity. Finally, it suggests some additional fall of material until $1947 \mathrm{~h}$, with only occasional rock falls thereafter.

To better understand the relationship of geophone signals to downhole activity, Los Alamos and LLNL took two types of measurements. First, Los Alamos at the Dutchess site (U7bm) and LLNL at the Dauphin site (U9cq) monitored geophone signals during a portion of the stemming operation at each site. In both cases they found that any geophone signals caused by the emplacement of stemming were below the detection threshold of geophones located at the distance of the recording trailer park.

Second, LLNL performed an experiment at hole U10bg. In this experiment rocks, weighing 1, 


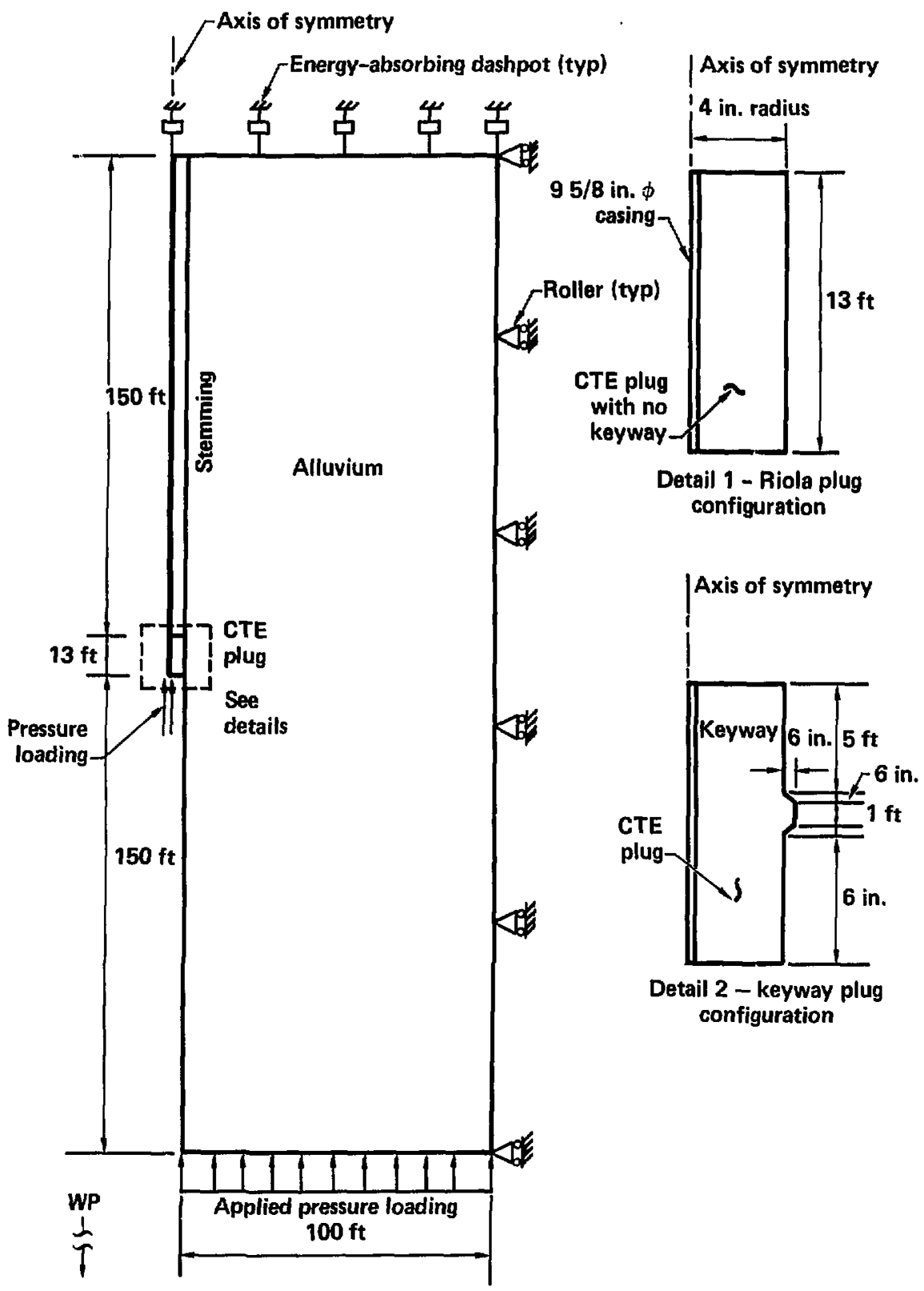

Figure 31. Axisymmetric finite element model. 
10 , and $100 \mathrm{lb}$ (within a factor of 2), were dropped dewnhole singly and in groups and the geophone signals were recorded. Signals from trailer park geophones located about $170 \mathrm{ft}$ from SGZ were recorded in $C P-9$, and those from the geophone array $(300,600$, and 900 distant from SGZ) were recorded in Trailer 973. The depth of hole U10bf was approximately the same as the distance between the Riola stemming platform and working print. No 1-lb rock was detected; however, $70 \%$ of the singly dropped $10-1 \mathrm{~b}$ rocks and $100 \%$ of all larger wicight drops were detected. Figure 32 show's the results of this experiment. In this range, the relationship of weight dropped to recorded signal appears to be exponential.

\section{Emplaced Plug Properties}

Several successful efforts have been made to emplace and recover downhole plug material. The purpose of these efforts was to ascertain the quality of emplaced plugs and to compare their emplaced properties with the properties of quality control samples.

Los Alamos performed two retrievable plug pours, hoth of which were recovered and broken up. The material in both plugs appeared to be poorly mixed and friable.

L.LNL performed a retrievable plug pour in hole U4ac, at a depth of $800 \mathrm{ft}^{1 \mathrm{t}}{ }^{\mathrm{B}}$ The plug ap- peared to be well mixed, and there was no evidence of major intrusions by native material. However, there was evidence that it had not cured completely and that its mechanical strength was significantly less than had been expected. Table 9 shows a comparison of downhole and QA sample strengths. While LLNL plug material QA samples undergo an isothermal $\left(140^{\circ} \mathrm{F}\right)$ cure for a fixed period, Los Alamos samples are cured at ambient temperature from the time of plug pour until within a few hours of the D-1 containment briefing.

1.LNL also retrieved samples of two pumped and one poured plug from U9ITS-U29 during the containment downhole system test. The pumpedplug sample [DISS (dowhole inverted pyramid sanipler) plug 2] contained large-scale inhomogeneities (regions containing only CTE and only gravel), and no mechanical testing was done on this sample. It also contained a considerable amount of water, and infrared spectroscopy indicated the sample was not cured. The pouredplug sample (DIPS plug 3) showed good mixing, but infrared spectroscopy indicated the sample was not cured. Its shear strength was $89 \mathrm{psi}$, and it had a flexure stiength of 262 psi. Testing of laboratory, field $\mathrm{QA}$, and dowhole samples was performed by A. Kusubov, A. E. Abey, and $S$. R. Trettenero, ${ }^{19}$ and the results are shown in Table 10.

\begin{tabular}{|c|c|c|}
\hline \multicolumn{3}{|l|}{ Beam flexure } \\
\hline Sample source & $\begin{array}{l}\text { Flexure strength } \\
\text { MC/J (psi) }\end{array}$ & $\begin{array}{c}\text { Standard } \\
\text { deviation (psi) }\end{array}$ \\
\hline $\mathrm{U} 4 \mathrm{ac} \mathrm{QA}$ & 857 & 56 \\
\hline U4ac downhole & 284 & 95 \\
\hline $\begin{array}{l}\text { Los Alamos history } \\
(12 / 76-5 / 78)\end{array}$ & 720 & 297 \\
\hline $\begin{array}{l}\text { LLNL history } \\
\text { ( last } 5 \text { years) }\end{array}$ & 630 & 98 \\
\hline \multicolumn{3}{|l|}{ Direct shear } \\
\hline Sample source & $\begin{array}{c}\text { Shear strength } \\
\text { (psi) }\end{array}$ & $\begin{array}{c}\text { Standarỏ } \\
\text { deviation (psi) }\end{array}$ \\
\hline U4ac sownhole & 103 & 19.6 \\
\hline Lab cured and prepared & 577 & 33.6 \\
\hline
\end{tabular}




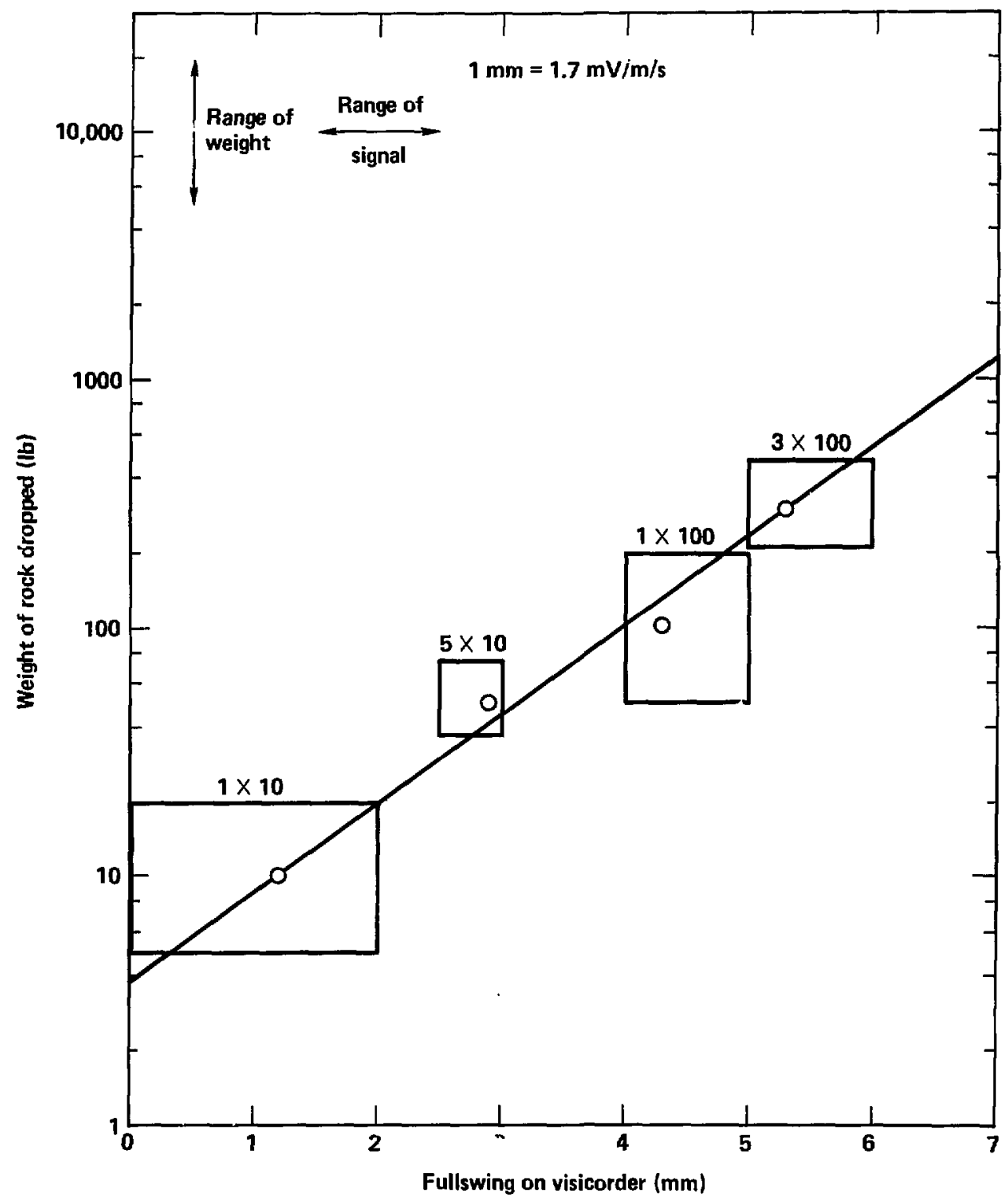

Figure 32. Weight of rock dropped vs geophone signal. 
Table 10. Strength of CTE plug materials.

\begin{tabular}{|c|c|c|c|c|}
\hline \multirow[b]{2}{*}{ CTE material } & \multicolumn{2}{|c|}{ 1-bar confining pressure } & \multicolumn{2}{|c|}{ 1000-bar confining pressure } \\
\hline & $\begin{array}{c}\text { Strain } \\
0.01 \\
\text { (bars) }\end{array}$ & $\begin{array}{c}\text { Strain } \\
0.10 \\
\text { (bars) }\end{array}$ & $\begin{array}{c}\text { Strain } \\
0.01 \\
\text { (bars) }\end{array}$ & $\begin{array}{c}\text { Strain } \\
0 . x n \\
\text { (bars) }\end{array}$ \\
\hline Laboratory LAE 59 & 50 & 70 & 300 & 500 \\
\hline Qualily Assurance LAE 59 & 50 & 70 & 280 & 500 \\
\hline $\begin{array}{l}\text { Extracted downhole LAE } 59 \\
\text { Hole U4ac }\end{array}$ & 2 & 10 & $\mathbf{5 0}$ & 120 \\
\hline "DIPS" plug No. 3 & 4 & 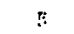 & 65 & 155 \\
\hline
\end{tabular}

\section{Conclusions}

If the likelihood of a radiation release from an uncollapsed event is to be minimized, some portion of the stemming column beneath the surface conductor must remain in place. After the stemming had fallen in hole U2eq, gas penetrated cracks between the surface conductor and surrounding grout, cracks in the grout, and around the mousehole and reached the surface.

To maintain the portion of stemming column above the stemming platform, the integrity of both the platform and the hole surrounding the platform must he maintained after the event. In the case of Riola $150 \mathrm{ft}$ of the hole in the region of the stemming platform became enlarged up to twice its original diameter, and only the core of the stemming platform supported by the plug support ring remains.
Evidence is insufficient to iscertain whether the hole or the plug failed first. The failures may have been simultaneous. However, the ctisappearance of $80 \%$ of the stemming platform cannot be explained by erosion alone, assuming a normal strength for the plug material. Moreover, the retrieved plug experiments provide strong evidence tizat the Riola stemming platform material was weak.

The use of stronger plug material, together with an appropriately located and shaped keyway, should considerably enhance the maintenance of stemming in the upper portion of the emplacement huie, thereby preventing recurrence of a Riola-mode release. 


\section{References}

1. D. N. Montan, Waste Gas Disposal ill Allizium, memorandum to H. L. McKague, Lawrenre Livermore National Laboratory, Livermore, CA (January 12, 1981).

2. C. F. S nith, Rioln Gas Sampling, Lawrence Livermore National Laboratory, Livermore, CA, memorar:dum RDS-WP-81-90 (1981).

3. E. C. Woodward, Riola Information for CEP, Lawrence Livermore National I.aboratory, Livermore, CA, memorandum UOPKL 81-55 (1981).

4. K. E. Raschke, Riola Soil Samplc Results, Lawrence Livermore National Laboratory, Livermore, CA, memorandum KER-7-82 (1982).

5. E. D. I.esses, Riola Graphical Soil Samplo Results, Lawrence Livermore National Laboratory, Livernore, CA. memorandum EL-01-82 (1982).

6. R. G. Miller, U2'y Post-Shot Hole Drilling Sumimary, Lawrence Livermore National Laboiatory, Livermore, CA, memorandum (July 6, 1982).

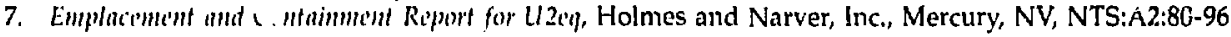
(j980).

8. H. - Watling, Rivla Rerie'iw, Lawrence Livermore National Laboratory, Livermore, CA, memorandum $80-C G-126(1990)$ ).

9. A. B. Casamajor, Enginering Eindmation of Rioln Containment, Lawrence Livermore National Laboratory, Livermore, CA, UCID-19164 (1981).

10. R. B. Evarts, The Riola lucident Prompt Relense Ri'sults, memorandum to J. Toman and J. C. Behne, Lawrence Livermore National Laboratory, Livermore, CA, memorandum RBE-8-81 (1981).

11. Intrim Report of Of fsite Surveillance for the Rioln Test of September 25, 1980. Envirnmental Protection Agency Environmental Monitoring Systems Laboratory-Las Vegas, Las Vegas, NV (September 1980).

12. W. A. Scoggins, Envirommental Surveillance Report for the Newadn Test Site (Jamusry 1980 through Dec'mber 1980), Department of Energy, Nevada, DOE/NV/00410-64 (1981).

13. P. H. Gudiksen and G. D. Greenly, Jr., Atmospheric Tramsport of Radionctivity fre the Rioln Event, Lawrence Livermore National Laboratory, Livermore, CA, memorandum UASG . : ' ; (1981).

14. J. R. Smith, Wud Flow Study --Riola, U2'n, Lawrence Livermore National Laboratory, Livermore, CA, memorandum UOPKL 81-15 (May 5, 1981).

15. R. P. Kennedy, S. A. Short, and W. Tong, Ground Shock Evaluation of the CTE Plug for the Li2eq Riola Ei'nt, Strictural Mechanics Associates, Inc., Newport Beach, CA (March 1981).

16. B. L. Maranville and B. A. Post, CTE Plug Erosion Test, Lawrence Livermore National Laboratory, Livermore, CA, ENN 81-24 (1981).

17. B. L. Maranville, Abrasion Resistance of Seweral Dowinhole Materials, Lawrence Livermore National Lahoratory, Livermore, CA, ENN 81-35 (1981).

18. W. E. Lowry, Summary of the Ll tac Retriced Plug Experiment, Lawrence Livermore National Labnratory, Livermore, CA, memorandum ENN 82-22 (1982).

19. A. Kusubov, A. E. Abey, and S. R. Trettenero, Lawrence Livermore National Laboratory, Livermore, CA, memorandum HPP 82-41-2098x (1982). 